\title{
Artificial Intelligence in Predicting Abnormal States in a Robotic Production Stand
}

\author{
Grzegorz Bojarczuk
}

Festo Sp. z 0.0., ul. Mszczonowska 7, 05-090 Janki k/Warszawy

\author{
Miłosz Mazur, Aleksander Wojciechowski, Mariusz Olszewski \\ Politechnika Warszawska, Wydział Mechatroniki, Instytut Automatyki i Robotyki, ul. św. Andrzeja Boboli, 02-525 Warszawa
}

\begin{abstract}
The aim of the described study is an engineering solution to the problem of the implementation of artificial intelligence methods in predicting abnormal, extremely emergency states in robotic production stands. This task results from the need to improve the operational reliability of automated and robotic production lines, thus rationalizing the utility and cost values of these lines. The available hardware solutions as well as the existing and newly introduced new procedures and IT platforms are described. In the hardware part of the work, electric servo drives and gears of a multi-chain tripod robot were used, configured with the Festo Automation Suite software, programmed with the KEBA controller and the developed KeStudio application program.
\end{abstract}

\section{Introduction}

Mechatronization, informatization and internetization (IT and OT) of production as well as full product lifecycle management (PLM-Management), which are an integral part of the concept of Industrial Transformation 4.0, have now become one of the main directions of the development of production automation and robotization, thus rapidly increasing the number of hardware and IT solutions available on the market [1-12]. This trend is perfectly illustrated by the statistics published in 2020 , which show that the number of IIoT (Industrial Internet of Things) devices installed in 2027 will exceed 41 billion, and another 127 devices will be connected to the Internet every second. In industrial practice, more and more workstands in production halls are equipped with IIoT Gateway - devices that allow for smooth data transfer between programs operating locally on controllers in control cabinets (e.g. information from sensors installed on devices, machines and production modules) and cloud applications (Cloud Computing), which allows for advanced computational data analysis with limited use of the computing power of processor hardware [27-30].

One of the most important tasks of digitized work stands is the ability to ensure continuous control of the condition of used

Autor korespondujący:

Mariusz Olszewski, marindustry4.0@gmail.com

Artykuł recenzowany

nadesłany 31.06.2021 r., przyjęty do druku 22.07.2021 r. devices and machines as well as early detection of abnormal states and failures based on the analysis of measurement data this ensures the possibility of predictive supervision and maintenance. At present, it is possible to use the studies of companies offering commercial predictive maintenance services (these are usually start-ups) or the offers of consulting companies or individual software for individual clients.

An example of such a company is the German holding elunic AG, offering consulting services in the form of a six-step plan that allows for the effective creation of a surveillance and data transmission system, assistance in establishing short-term and long-term such an undertaking and advice on financing the entire project [33-35]. In addition, as part of the service, it provides enterprises with the support of its own experts, experienced in the issues of digitization of industry and predictive supervision over the behavior of industrial stands (Fig. 1). The advantage of purchasing such a service is therefore the acceleration of the modernization process of production stands, the construction of an IT system responsible for the prediction of abnormal states in production, avoiding potentially possible errors and oversights, and optimization of the received application. The company also distributes its own IT system that allows for data visualization (Dashboards) and the implementation of machine learning algorithms, allowing for predictive maintenance of production stands. The program, in addition to the basic functionalities of the data supervision system, also allows for advanced supervision over human resources and assistance in making commercial decisions, e.g. in finding the cheapest spare parts for the planned maintenance and repairs. The software application has a modular structure and standardized interfaces for data exchange, which ensures the possibility of system development and easy writing of modifications also by users.

A slightly different concept of visualization and supervision of transmitted data and their analysis for the predictive detec- 
tion of abnormal states is available at C3 AI. The company is a leading enterprise AI software provider for building enterprise-scale AI applications and accelerating digital transformation. Unlike the holding company, elunic AG, mainly offers ready-made software packages. The solution is a comprehensive application with separate modules responsible for data integration, saving and reading data from popular containers, easy information validation and definition of the availability policy (C3 AI Data Studio), quick development, training and development of artificial intelligence algorithms (C3 AI ML Studio) and creating graphic visualizations (C3 AI Applications Studio) (Fig. 2). The company also provides modules that allow for independent development of the application - a program that facilitates version management (C3 AI DevSecOps Studio) and a store that allows you to buy and sell extensions to software written by third parties (C3 AI Marketplace). All the modules described above are part of the C3 AI Suite-Software with a model-based architecture, the main selling point of which is the introduction of an additional abstraction layer that allows the creation of applications using artificial intelligence methods with a minimum number of program code written (to a large extent, it was possible to achieve thanks to the use of conceptual models).

The C3 AI Suite system appears to be one of the few currently existing comprehensive solutions for collecting data from devices connecting to the IIoT and providing predictive supervision capabilities, while having a large portfolio of real use cases in the industry. The disadvantage of this solution is that, despite numerous improvements in terms of the way of writing software for a programmer, on the basis of promotional materials, one can get the impression that it requires from its users, in order to be fully effective, above-average knowledge of machine learning and computer science. This may discourage smaller companies from using this IT system that want to provide predictive supervision on the production line, while at the same time lacking significant IT staff.

Another product currently available on the market is the HALerium system of the German company Erium GmbH [36]. The assumption of the program is to combine three aspects of supervision over the industrial application: controlling the information obtained from the transmitted data, the mere prediction of faults and necessary maintenance, and supporting decision-making on the actions that must be taken to ensure uninterrupted production. The application seems to be quite advanced in terms of the possibilities offered to adjust the method of controlling the process to the needs and preferences of the customer, but at the moment the Erium system has only a single history of successful use - supervision over manufactured parts for BMW cars. This makes it difficult to define the real, practical capabilities of the system.

Both of these possibilities, however, are not related to the creation of complete, comprehensive, universal solutions. In the described project, for the implementation of artificial intelligence methods responsible for the above-described functionality, the Scraitec system by the Resolto company with the Festo holding was used $[31,32]$.

\section{Robotized Test Stand}

The described task of solving the problem of the implementation of artificial intelligence methods in the prediction of abnormal and extreme emergency states in robotic production stands resulted from the extensive work currently carried out at the Application Center of Festo Polska, aimed at improving the operational reliability of automated and robotic production lines, thus rationalizing utility values and costly operation of these lines [13-18]. To carry it out and perform the necessary measurements, a stand equipped with a multi-chain robot, available from the Festo AG \& KG holding, was used [37, 38].

The interest of industrial sectors in this type of construction of production stands results from the spectrum of their possible, fully robotic applications, from the confectioning and packaging of small products, e.g. in the food and pharmaceutical industries, through the assembly of mechanical and electromechanical products, e.g. in the precision and mechatronic industries, until to perform complex technological micro- and nanooperations, e.g. in the electronics and processors industries (Fig. 3) [19-21].

The EXPT series tripod used in the research belongs to one of two groups of solutions for multi-chain mechanisms, characterized by a parallel kinematic structure in which there are open or closed kinematic structures. In the case of a tripod, equipped in the regional part with three servo drives, this structure is closed, the so-called Stewart's platform, which is the link, through ball joints, of these three kinematic chains. By embedding additional servo drives of the local part of the mechanism on the Stewart platform, it is possible to increase the number of degrees of

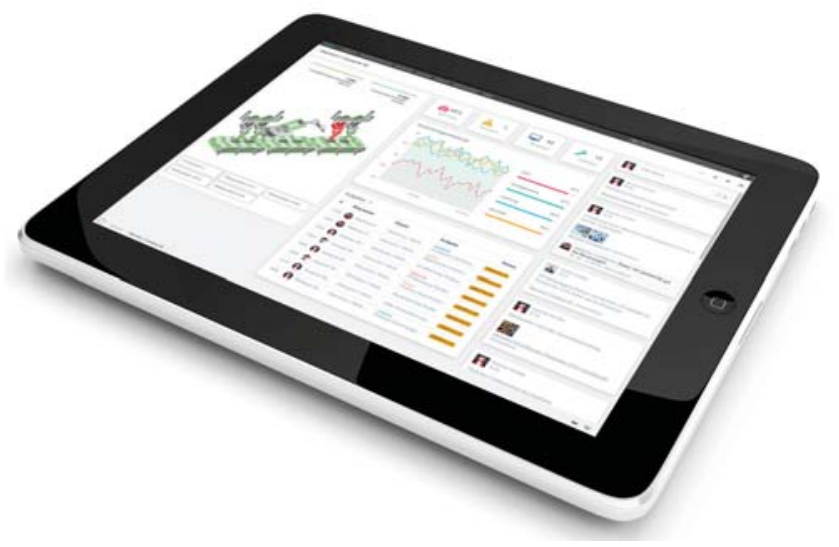

Fig. 1. View of the promotional window of the predictive system for supervising the behavior of industrial stands and production lines of the elunic AG holding

Rys. 1. Widok promocyjnego okna systemu predykcyjnego nadzoru nad zachowaniem przemysłowych stanowisk i linii produkcyjnych holdingu elunic AG
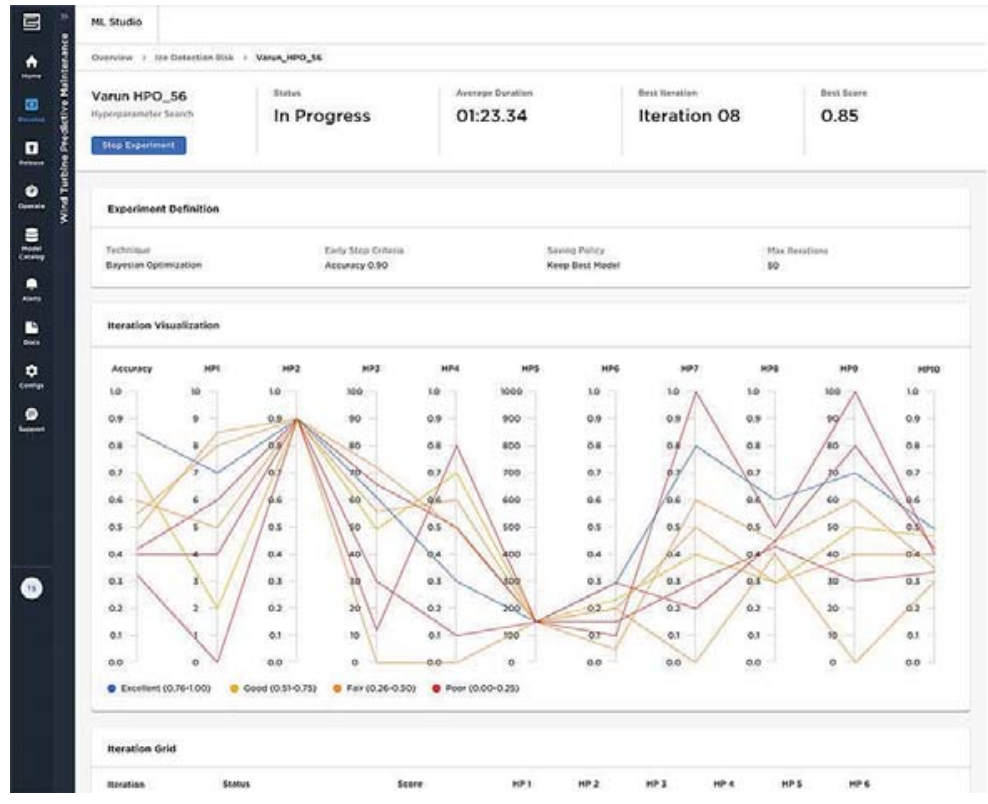

Fig. 2. Screen illustrating the course of model selection used in machine learning of the C3 Ai Suite system (C3 Al ML, Studio) Rys. 2. Ekran ilustrujący przebiegi doboru modelu używanego w uczeniu maszynowym systemu C3 Ai Suite (C3 Al ML, Studio) 


\section{Kontroler robotyczny C5}

Schemat systemu

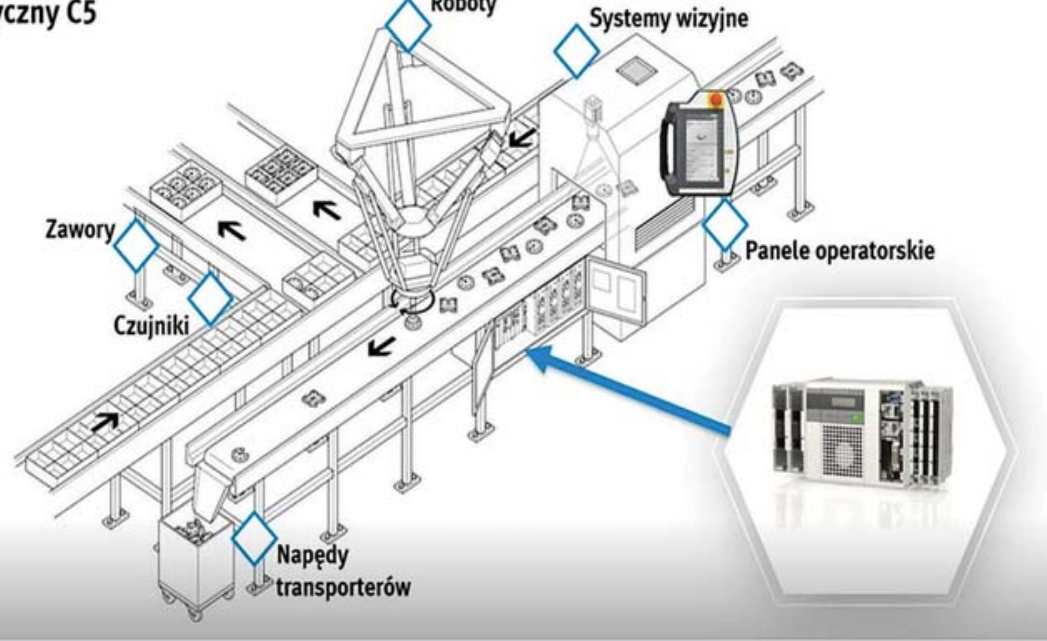

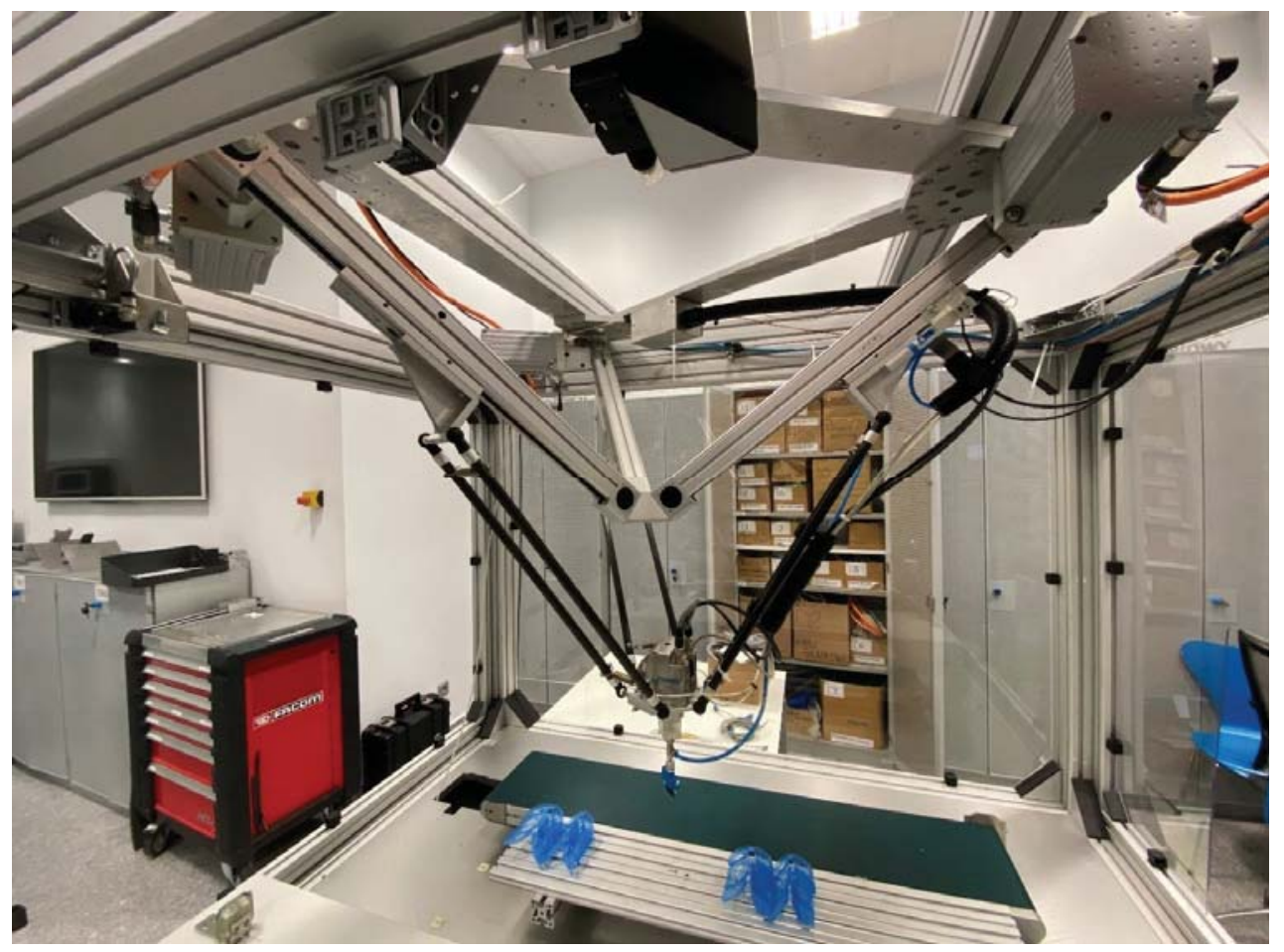

Fig. 3. Diagram of an exemplary implementation of a robotic transport system with a $\mathrm{C} 5$ robotic controller by KEBA and an EXPT tripod by FESTO AG \& KG

Rys. 3. Schemat przykładowej realizacji zrobotyzowanego systemu transportowego ze sterownikiem robotycznym C5 firmy KEBA oraz tripodem EXPT holdingu FESTO AG \& KG

Fig. 4. EXPT three-chain robot from the FESTO AG \& KG holding used on a robotic stand for a Pick and Place transport application Application Center Festo Polska Rys. 4. Robot trójłańcuchowy EXPT holdingu FESTO AG \& KG wykorzystany na stanowisku zrobotyzowanym do aplikacji transportowej typu Pick and Place Centrum Aplikacji Festo Polska

mobility, e.g. to four or five degrees, which improves the functionality of its solution (Fig. 4). The advantage of tripods is the rigid structure of the entire mechanism, which, compared to conventional mechanisms with serial chains, is characterized by a much higher accuracy of the effector positioning (repeatability of the effector position at the level of hundredths of a millimeter), which allows robotization of the production of devices in the micro- and nanoscale mentioned. A certain disadvantage of such solutions is the small working space, which is excessively compensated by high speeds of the effector movement, unattainable in the case of mechanisms with other kinematic structures [22-25].

The regional part of the tripod mechanism consists of three actuators from the DGE 25-360 series, with a toothed belt transmission, with an internal, protected roller guide. The actuators are driven by electric motors from the EMMS-AS series - they are dynamic, brushless, permanently excited, synchronous servo motors, equipped with an absolute encoder and an electromagnetic brake (Tab. 1) [37-40].
Tab. 1. Values of selected operational parameters of the EXPT tripod mechanism in the test stand

Tab. 1. Wartości wybranych parametrów użytkowych mechanizmu tripoda EXPT w badanym stanowisku

\begin{tabular}{|l|c|}
\hline Parameter & Value \\
\hline Useful load of tripod & Max. $5 \mathrm{~kg}$ \\
\hline Work space of tripod & $\pm 50 \mathrm{~mm}$ \\
\hline Positioning repeatability of tripod & $\pm 0,01- \pm 0,1 \mathrm{~mm}$ \\
\hline Accuracy of trajectory reproduction at a speed of $300 \mathrm{~mm} / \mathrm{s}$ & $3 \mathrm{~m} / \mathrm{s}$ \\
\hline Effector speed with a load of $1 \mathrm{~kg}$ & $50 \mathrm{~m} / \mathrm{s}^{2}$ \\
\hline Effector acceleration with a load of $1 \mathrm{~kg}$ & $400 \mathrm{~V} \mathrm{AC}$ \\
\hline The nominal voltage of the motors & $3,3 / 15 \mathrm{~A}$ \\
\hline Nominal and peak current of motors & $3,24 / 12,5 \mathrm{Nm}$ \\
\hline Nominal and peak torque of motors & $9 \mathrm{Nm}$ \\
\hline The torque holding the brakes & \pm 0.3 \\
\hline
\end{tabular}




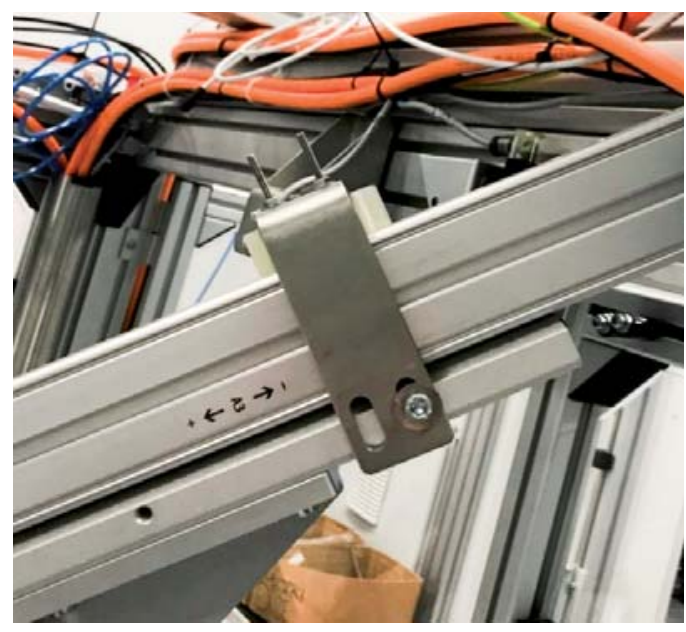

a)

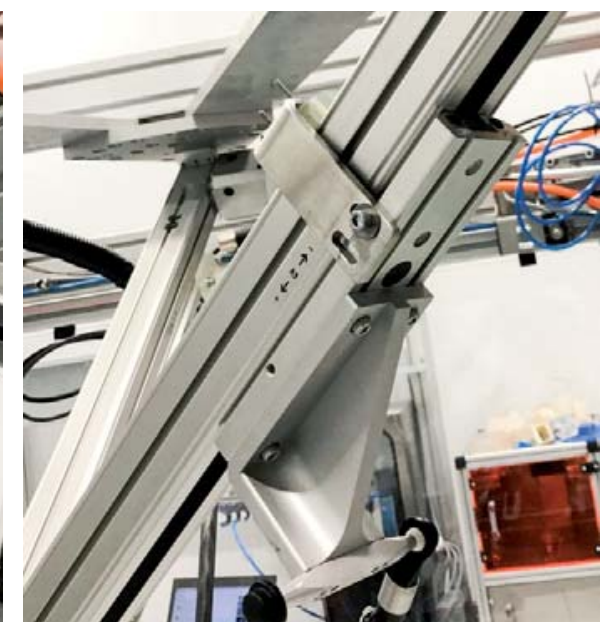

b)

Fig. 5. Simulation of an abnormal situation in the project: a) structure increasing the friction force in one of the tripod members, b) fixing this structure to the slider of the motor gear actuator

Rys. 5. Symulacja sytuacji anormalnej w projekcie:

a) konstrukcja zwiększająca opory ruchu jednego z członów tripoda, b) zamocowanie tej konstrukcji do suwadła elektrycznego, silnikowego aktuatora przekładniowego

For the hardware simulation of abnormal behavior of the stand, a change in the resistance to motion of the guides of the tripod mechanism was adopted. A very simple mechanical structure was used, mounted on the actuator slide of each of the kinematic chains, pressing the element with the tape stuck on it, increasing the friction, against the guide. It was assumed that this would be equivalent to the long-term exploitation of the mechanism and wear of the mentioned guides, which of course also changes the normal dynamic behavior of the tripod. By increasing the pressure of said element, it was possible to set correspondingly higher wear and tear and simulate the transition into an abnormal or even emergency state (Fig. 5).

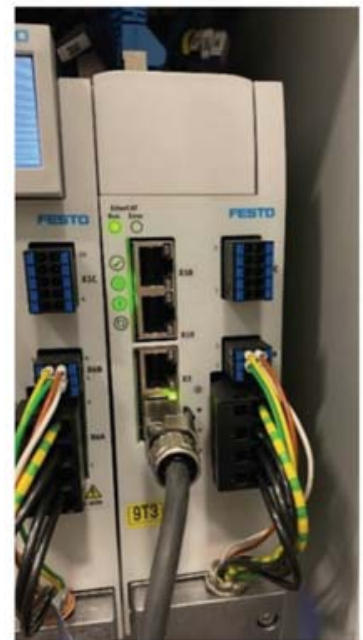

a)

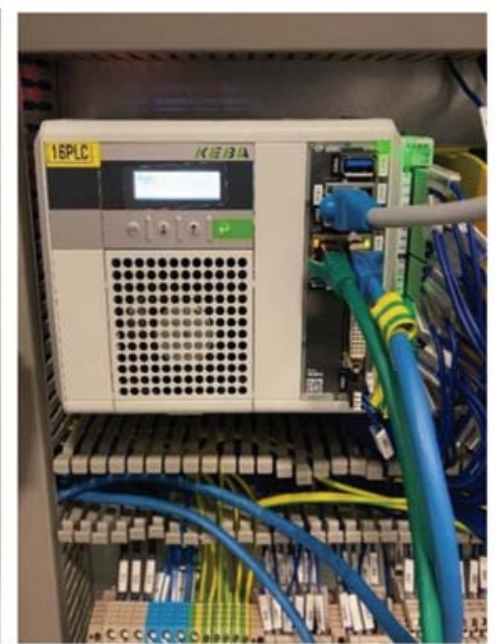

b)

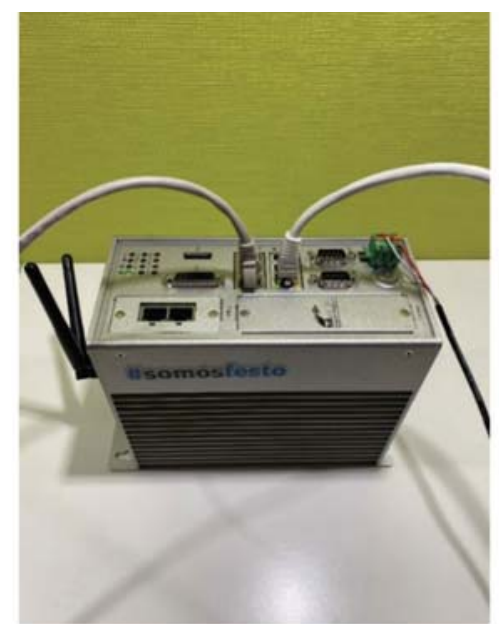

c)

\section{Controlled Test Stand}

The main control unit located in the control cabinet is the controller robotic C5 produced by KEBA, cooperating with holding Festo [41]. It is a modern system for controlling the movement of robot mechanisms, which is a combination of a conventional PLC controller, a motion controller responsible for axis synchronization and a robotic controller. This very efficient unit enables the implementation of practical control tasks advanced in its complexity. It is characterized by modularity and scalability - you can connect the controller with many servo drives and robot mechanisms. This solution allows you to control the entire machine or application from one controller. The software used with the C5 controller is KeStudio, which allows access to all three layers of the robot from the level of one project, which means that you can generate a robotic program in the application, a logic program for technological process control and implement the Motion function for synchronous control of additional parts of the robot's mechanism and technological process (Fig. 6).

The C5 controller has a built-in EtherCAT master for fast data exchange. At the same time, drives requiring synchronous communication and distributed I/O systems can be connected in the same network, which simplifies the electrical structure of the system and saves wiring. In addition, there are two built-in Ethernet ports for communication with internal or external devices. The system allows you to control each robot supplied by Festo. The efficient computing unit allows you to connect up to eight Tripod mechanisms to one C5 controller, used in Pick and Place applications, including keeping up with the objects moved on the production line belt. Controller enables programming of the robot's movements through a simple and intuitive robot programming language - KAIRO. Expansion cards with various functions are also available: digital I/O, analog I/O and encoder cards [39, 40].

Fig. 6. Power supply and control devices for the test stand with EXPT tripod: a) CMMT-AS servo driver by FESTO AG \& KG with connected: temperature sensors, brakes, motor phases and an encoder, b) KEBA AG robotic controller with a digital module and connected: I/O signals, servo drives (EtherCAT), Teach Pendant and IPC (Ethernet), c) industrial computer (IPC) with balenaOS operating system, optimized for running software packages (containers), including packages responsible for the operation of the Scraitec platform

Rys. 6. Urzadzenia zasilania i sterowania badanego stanowiska z tripodem EXPT: a) sterownik serwonapędu CMMT-AS produkcji FESTO AG \& KG z podłączonymi: sensorami temperatury, hamulcami, fazami silnika i enkoderem, b) kontroler robotyczny produkcji KEBA AG z modułem cyfrowym i podłaczonymi: sygnałami I/O, serwonapedami (EtherCAT), programatorem (Teach Pendant) i komputerem IPC (Ethernet), c) komputer przemysłowy (IPC) z systemem operacyjnym balenaOS, zoptymalizowanym do uruchamiania pakietów oprogramowania (kontenerów), w tym pakietów odpowiedzialnych za działanie platformy Scraitec 


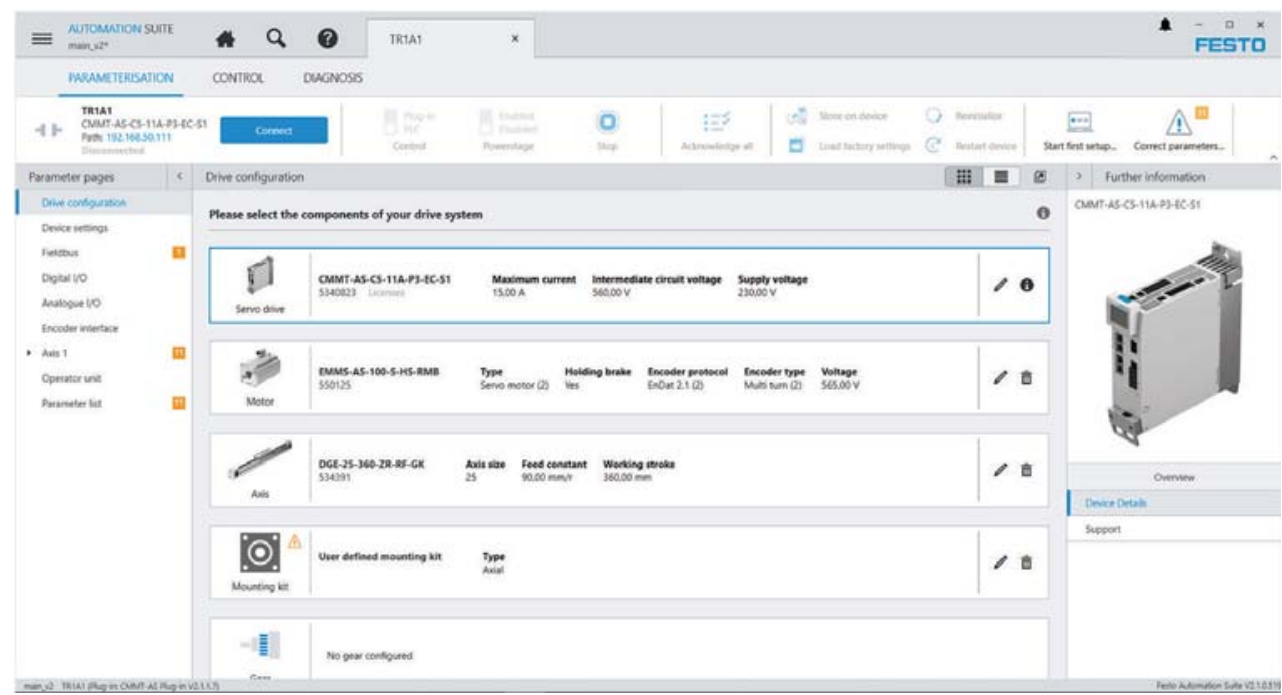

Fig 7. The main view of the servo driver window with added FESTO Automation Suite software components, allowing for the configuration and synchronization of the operation of individual stand and tripod servo drives Rys. 7. Główny widok okna sterownika serwonapędu z dodanymi komponentami oprogramowania FESTO Automation Suite, pozwalającymi na konfigurację i synchronizację działania poszczególnych serwonapędów stanowiska i tripoda

The C5 controller comes with a DM 570 hybrid digital module from the KeConnect C5 series, which is a card with a digital I/O function. It provides eight inputs with individually configurable filters and eight digital outputs with a quick disconnect function.

On the stand used in the project, the C5 controller acts as a computer that controls the servo drives and I/O signals. Festo CMMT-AS servo drives were used to implement the tripod's trajectory. This series offers universal servo drives for PM (Permanent Magnet) synchronous servo motors with power up to $6000 \mathrm{~W}[42,43]$. The servo drives have an integrated single-phase/three-phase 230/400 V mains connection, mains filter and braking resistor. They allow for torque, speed and position control and support such communication protocols as EtherCAT, ProfiNet, EtherNet/IP and Modbus (Fig. 7) [26].

The stand was equipped with a KeTop T70 operator panel used for commissioning and service activities. The panel contains many ready-made wizard procedures that facilitate the setup or configuration of complicated or time-consuming activities such as tracking, TCP collecting, workspace monitoring and a palletizer. As an operator panel (Teach Pendant), it is equipped with safety buttons and a three-stage Enabling Button.

The project uses an industrial personal computer (IPC) with the balenaOS operating system optimized to run containers (software packages), including those responsible for the operation of the Festo AX and Scraitec platforms.

The IPC used is in fact a netIOT Edge Gateways solution combining automation networks with cloud-based or IIoT (Industrial Internet of Things) applications. As a web-based editor for IIoT connections, it uses the Node Red development tool to configure data flow in devices.
Using the platforms available on an industrial computer, a model using a machine learning algorithm to detect anomalies at a robotic stand was taught later in the project, and data from the manipulator was visualized.

\section{Configuration of the Test Stand}

Special Festo Automation Suite (FAS) software was used to configure the servo drives of the test stand, which allows for a reliable start-up of the entire set of its drives. The software enables the parameterization, programming and operation of all Festo components used to automate and robotize the stand or as a whole production line. This is done by connecting the IPC computer to the controller via the EtherNet/IP protocol. After scanning, detecting and adding the servo drive to the project, it is possible to add individual components based on the designations of the actual components on the stand or, if the servo drive has been previously configured, it is possible to load the current configuration from the controller and view the drive set (Fig. 8).

After establishing a direct connection with the controller in the active control mode, it is possible to control the servo drive and watch the current values of the device parameters. Also in this mode, finishing the configuration process, homing was carried out, consisting in releasing the brakes, manually shifting the actuator drive slide to the end position and this position was remembered by the controller.

Creating a project begins with going through the project wizard, in which you need to add the necessary libraries of the

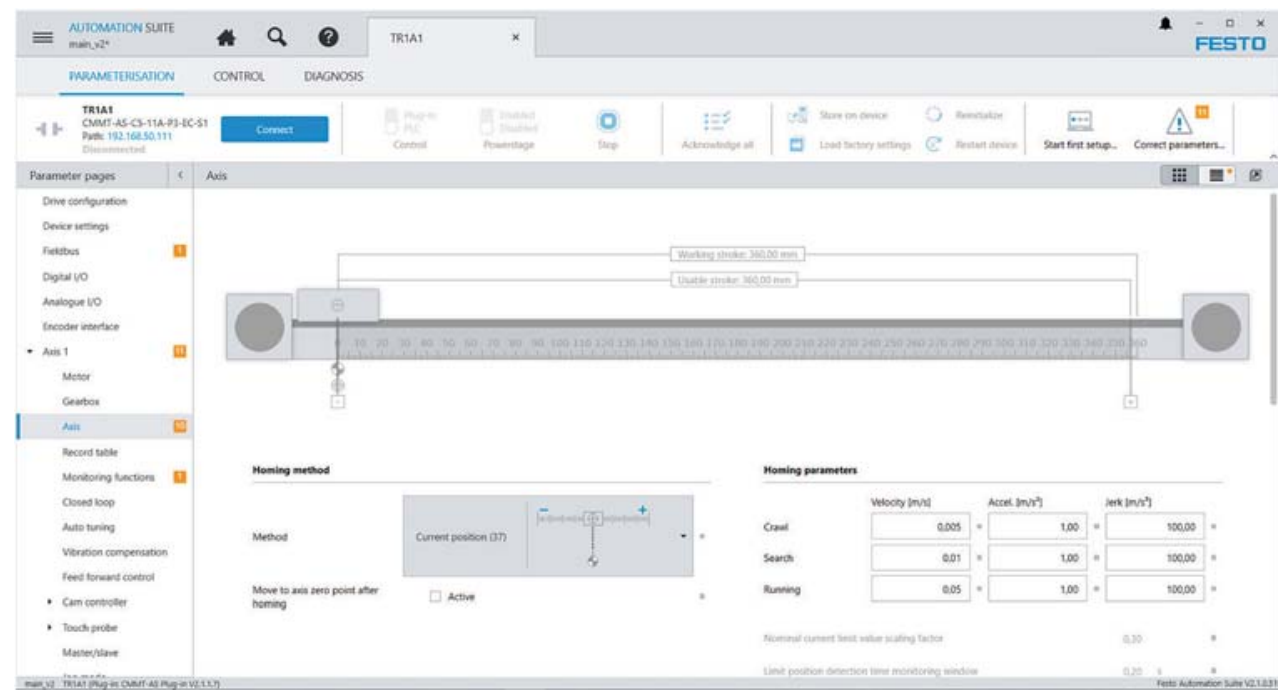

Fig. 8. Configuration of the selected servo drive in the FESTO Automation Suite software, which consists in determining the working stroke, usable stroke and selecting the homing method Rys. 8. Konfiguracja wybranego serwonapędu w oprogramowaniu FESTO Automation Suite, polegająca na określeniu skoku roboczego, skoku użytkowego oraz wybraniu metody bazowania 
drives used, as well as specify the controller, operator panel and the type of robot used in the robotic application. After its completion, the main program window is displayed.

The root of the created project tree is the control device - the KEBA CP520/C controller used, which has the following tabs:

- Diagnostics containing tabs: Messages and Trace,

- Expert Entries - allows you to add communication with, for example, Modbus server,

- Messages Editor - allows you to create your own messages,

- PLC Logic - the part responsible for the logic of the PLC program and as part of the application includes:

- Folders, global variables and programs written in various available languages: CFC, ST, FBD, SFC, LD,

- Library Manager - allows you to add the necessary libraries,

- Symbol Configuration - allows you to select variables to be sent using TCP communication,

- Task Configuration - allows you to add tasks and set the frequency with which individual programs assigned to this task are to be called,

- Trace - enables recording graphs of selected variables declared in available programs and exporting graphs,

- TeachControl - the part responsible for programming robotic movements containing:

- Application - allows you to declare variables available to all robots,

- Tripod (or another robot) - allows you to create projects with programs available only for this specific robot,

- TC Symbol Configuration - allows you to select variables from the robotic part to be visible in the PLC part,

- Visualization - enables the creation of visualization on the operator panel,

- ECAT - allows devices to be connected via EtherCAT communication:

- KeBus - a tab used for internal communication, when expansion cards are directly plugged into the controller,

- OUT0 - tab used for communication with external devices, such as drives,

- Ethernet 0 - Ethernet/IP port with a variable IP address enabling connection with an external device that supports this communication, e.g. IPC,

- Ethernet 1 - Ethernet/IP port with a fixed IP address intended for connection with the operator panel,

- Robots - allows you to add robots.

After the initial configuration, the project was uploaded to the controller and logged in to check the correct connection with the network card and drives, and then using the operator panel in the learning mode, test movements of each actuator were made to check the compliance of the direction of movement so that in the global system, while increasing the coordinate of the vertical movement Z, the movement of the Tool Center Point (TCP) towards the lower extreme position was observed.

\section{Communication in the Test Stand}

The design of the system for transmission and supervision of data from measurements performed during the robot's operation began with ensuring communication of the robotic controller, supervising the execution of the robotic program by the mechanism, with the software part responsible for the predictive analysis of the position and the graphical representation of the data.

First, the data that must be sent between the controller, located in the control cabinet, and an external industrial computer, on which the application will operate, which will properly handle and supervise them, were defined. These are:

- General information about the robotic workstand:

- Are the mechanism drives powered?

- Is the mechanism moving at any given moment?

- Is the mechanism executing a program at the moment?

- Has a running program been interrupted?

- Has the running program been completed?

- Has there been an error?

- Information about the location of the individual drives of the mechanism,

- Information about the speed of the individual drives of the mechanism,

- Information about the moments realized by individual drives of the mechanism.

To ensure easy implementation of the system for the already existing workstands, for the transmission of the above-mentioned data, it was decided to use one of the communication protocols that use Ethernet transport protocols to transfer information and supported by default in the basic version of the KEBA C5 controller used in the control cabinet - these are Modbus TCP/ IP and OPC UA (libraries enabling easy implementation of protocols are available with the basic version of the KeStudio environment) [46, 47].

When comparing the two communication protocols, one should start with the statement that OPC UA has incomparably greater configuration options than the highly structured Modbus TCP/IP, giving the designer freedom over the communication method, the type of data transferred thanks to the use of object-based data models, and also over the method of ensuring the security of transactions. It is even possible to use the OPC UA protocol in conjunction with Modbus TCP/IP, e.g. by using the framing method of the second protocol for data transport, while maintaining the flexibility of the first protocol. On the one hand, such freedom may allow you to choose the most optimal communication method for the prepared application. On the other hand, it significantly increases the difficulty of the system implementation task itself, placing a considerable responsibility on the system designer - the effectiveness of communication in the created application and its security will largely depend on the work put into developing the system design. In extreme cases, this may lead to a situation in which the lack of experience with the technologies used by OPC UA will allow malware to easily exploit the weaknesses that have arisen. The flexibility of the standard solutions also makes it more difficult to maintain than the well-documented and tested Modbus TCP/IP [49].

Taking into account the advantages and disadvantages of both protocols, it was decided to use the Modbus TCP/IP protocol in the project, which offers a simpler and faster solution. It was decisive, inter alia, finding that the more advanced features offered by the OPC UA protocol would not be properly used anyway (Fig. 9).

The next task of solving the communication problem in the realized project was the implementation of two implementations: - Modbus TCP/IP server on the KEBA C5 robot controller and

- Modbus TCP/IP client on the industrial computer (IPC) side.

The first task was:

- importing the K_ModbusBase library, which is one of the basic extensions available for the KeStudio environment, making it much easier to configure communication,

- creating a new ModbusTask in the project tree (with a cycle time of $20 \mathrm{~ms}$, corresponding to the interval between down- 
Fig. 9. Implementation of the Modbus TCP/IP server on the KEBA C5 robotic controller, written in the ST language in the KeStudio software by KEBA AG

Rys. 9. Implementacja serwera Modbus TCP/IP na kontrolerze robotycznym KEBA C5, napisana w języku ST w oprogramowaniu KeStudio firmy KEBA AG

IF bRestartServer THIN

stMBstatus := ModbusServer_Restart();

bRestartServer := FALSE;

BND_IF

PO3: LRBAL;

PO4: LRBAL:

ve11: LRRAL:

po1:= T1_A1.ActualPosition;

K_SystemCa11Library.SysMem.SysMemCpy (ADR (GVL_Modbus.dataPoint.positionofAxis1 [0]), ADR(po1), 8):

po2 : = T1_A2.ActualPosition;

K_SystemCallLibrary.SysMem.SysMemCpy (ADR (GVL_Modbus.dataPoint.positionofAxis2 [0]), ADR(po2), 8); po3 := T1_A3.Actualposition;

K_SystemCallLibrary.SysMem.SysMemCPy (ADR (GVL_Modbus.dataPoint.positionofAxis3 (0]), ADR (po3), 8); po4:= I1_A4.Actualposition;

K_SystemCa11Library.SysMem.SysMemCpy (ADR (GVL_Modbus.dataPoint.positionofAxis4 [0]), ADR (po4), 8);

vel1:= T1_A1.ActualVelocity:

K_SystemCa11Library.SysMem.SysMemCPy (ADR (GVL_Modbus.dataPoint.velocityofAxis1 [0]), ADR(ve11), 8); ve12 := T1_A2.Actualvelocity;

K_SystemCa11Library.SysMem.SysMemCpy (ADR (GVL_Modbus.dataPoint.velocityofAxis2 [0]), ADR(ve12), 8);

vel3:= I1_A3.Actualvelocity;

K_SystemCal1Library.SysMem.SysMemCpy (ADR (GVL_Modbus.dataPoint.velocityofAxis3 [0]), ADR(ve13), 8);

vel4:= I1_A4.Actualvelocity;

K_SystemCa11Library.SYsMem.SysMemCpy (ADR (GVL_Modbus.dataPoint.velocityofAxis4 (0]), ADR (ve14), 8);

24) GVL_Modbus.index :=0;

loading subsequent data by the client, the poll rate), responsible for calling the "PRG_Modbus" program, in which part of the functionality related to server maintenance will be performed,

- writing the content of the "PRG_Modbus" program (performed, as mentioned before, every $20 \mathrm{~ms}$ ), enabling the server to restart by setting the RestartServer flag by the user, and assigning to the previously described variable values of position and speed, which are mapped values of real signals received from drive controllers (T1_A1 - reference to the first tripod actuator, etc.). In order to obtain the previously described memory division, the "SysMemCpy" function available in the $\mathrm{K}$ SystemCallLibrary was used, which copies a specific block of memory between the given pointers, being its arguments,

- writing the "CollectTorqueData" program, the purpose of which is, similarly to the "PRG_Modbus" program, appropriate assignment of moment values to appropriate global variables. This program will be executed in a much shorter work cycle (the program will be called in the MotionTask cycle - every $4 \mathrm{~ms}$ ). Information on the state of the robot is collected as part of the "GettingRobotInformation" action, triggered in the previously written "PRGKairoExecution" program. It is possible thanks to the use of the "FBExecuteKairo" block, which allows to obtain basic data on the current working state of the robot and its control from the PLC level (mechanisms available in the K_RobotControl library are used here) (Fig. 10).

- the last activity of this task that had to be performed was the configuration of the network settings of the server itself and the assignment of data stored in global variables to the appropriate registers. In the KeStudio environment, this is done under the Expert Entries tab. After the registers were assigned, the server implementation was completed, it became ready for data transfer, which was checked using the free evaluation version of the Modbus slave simulator software used to simulate the client application.

The second task, i.e. the implementation of the Modbus TCP/IP client on the side of the industrial computer, consisted in:

- developing a client application using the Modbus TCP/IP protocol in the Node-Red programming environment (implemented on IPC in the form of a balenaOS docker container), allowing for intuitive handling of data flow using graphical programming (individual functions are represented by blocks, sending data through the connecting wires). IPC has two independent Node-Red programs, using ports 1880 and 2880. The first one is responsible for sending data related to their visualization in FestoAX, the second - is responsible for transferring data between applications. This program, called

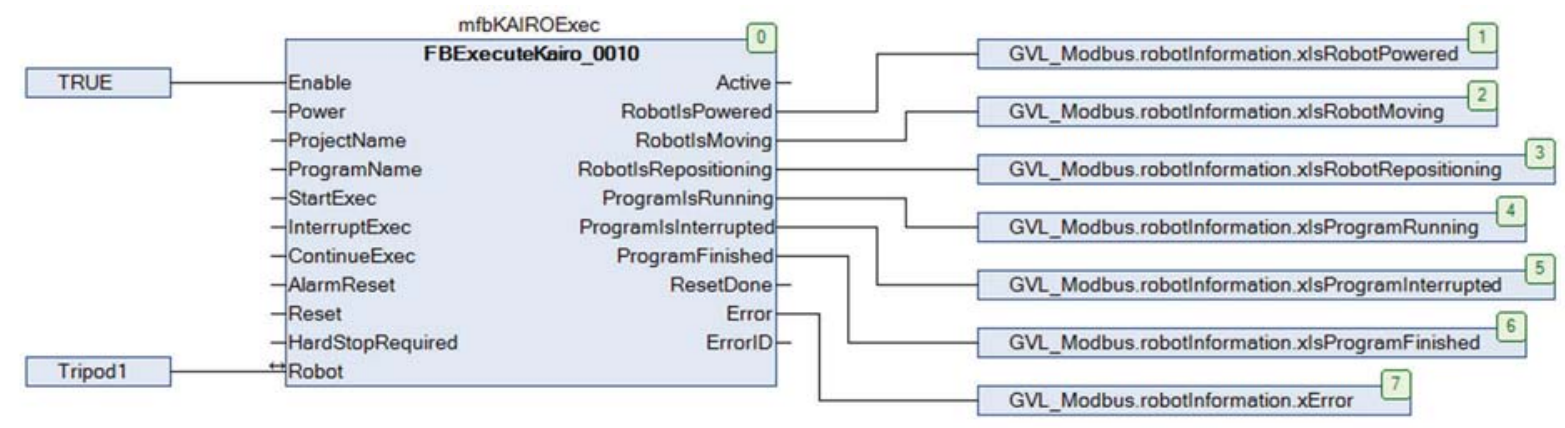

Fig. 10. Robot control software block in CFC language, allowing to transfer measurement signals using Modbus TCP/IP communication

Rys. 10. Blok programowy sterowania robotem w języku CFC, pozwalający na przesyłanie sygnałów pomiarowych przy użyciu komunikacji Modbus TCP/IP 
data flow (Flow) is responsible for the proper handling of data coming from the Modbus TCP/IP server. The Modbus-Read Node in the program called DataFromModbusTCP is responsible for sending questions to the server, coming from an additional library implementing the communication specified by Modbus TCP/IP [44, 45].

- creating a global variable, named KEBA, responsible for storing the network settings of the server to which the "DataFromModbusTCP" block directs queries. It contains information about the version of the Modbus protocol used (connection via the TCP/IP transport protocol), the IP address and the server port number, as well as information about the time after which the timeout is to take place and then, after which you should try to connect again, Then the data goes to the "UnpackModbusSubflow" subroutine, in which JSON objects are created from raw data. The data for the visualization in FestoAX is continuously transferred to the "FestoAxBroker" block. In turn, the data to be transferred to the Scraitec system are collected in the „join" block until the appropriate flag is given to it, related to the execution of the robotic program by the tripod,

- developing of the subroutine "UnpackModbusSubflow" to improve the readability of the data flow in the main data transfer program. It contains function blocks whose task is to divide the given data according to a specific logic. First, the raw measurement results received from the server in the form of a 119-element array are given to the subroutine through the Input1 block. The "sliceForVariables" function block divides this table into 4 parts - the first contains information about the robot and after creating a JSON object from it by the "InfoPointCreator" function - it is given to the Output 1. On its basis, the "CheckingIfDataIsRelevant" procedure calculates the state of the flag provided to the Output 3 block, specifying whether the data should be submitted for analysis by the Scraitec system. The other three parts are: a table containing the position of all actuators, a table containing their speeds of movement and a table containing the moments realized by the actuators. Then all four - element arrays of WORD type variables are converted to decimal form using the "WordArrayToNumber" algorithm (functions are written in the JavaScript programming language, in which 64 -bit variables store numbers). The newly created decimal values are then grouped with join blocks so that the functions "FestoAXPointCreator" and "ScraitecDataPointCreator" can create JSON objects from them, sequentially given on Output 2 and 4 .

A program written in this way in Node-Red allows for the creation of correct communication with the Modbus TCP/IP server and ensures effective use of the collected data in the test stand, including its transmission using broker-type procedures.

\section{Visualization, Supervision and Data Analysis in the Test Stand}

The IT system responsible for visualization, supervision and data analysis is created on an external industrial computer (IPC), with loaded balenaOS software, which is an operating system for supervising a number of devices based on the Linux architecture. This solution allows the resources of a single IPC to be separated so that it can simultaneously effectively provide communication and network traffic, perform analyzes, handle several databases and display visualization in the user interface. This is due to the separation of individual parts of the program into a container type, managed by a program called docker [45, 46].

An important issue is to ensure communication between individual containers so that, for example, the data received by the part of the program responsible for retrieving information from other devices can be saved in the database. The problem can be solved through the use of message broker - software, which allows for a smooth transition between different protocols, sending information and organizing the communication. The project uses the Mosquitto broker that allows the use of the MQTT protocol (Message Queue Telemetry Transport), introducing publish and subscribe mechanism, in which devices, when sending messages (publishing), post them on specific channels (distinguished by specifying topic). These channels are listened to by devices that want to receive the information (subscribers) (Fig. 11). Subscribers and publishers do not know about each other's existence, ensuring the security of transmission and the effectiveness of the solution obtained [48].

There are two independent brokers in the project. The first is responsible for internal communication between the databases storing information in FestoAX and connecting both Node-Red, the second - is an internal Scraitec broker connecting the internal databases of the system and the control responsible for the system logic.

The FESTO AX (Automation Experience) platform was used to visualize data and display messages about anomalies from the robotic stand, which enables the creation of dashboards supervising the operation of the stand. The platform is currently a commercially unavailable product of Festo, which is intended to enable data supervision, including through artificial intelligence algorithms based on a solution provided by Scraitec. In the future, the possibilities provided by the Scraitec platform are to be available from the FESTO AX platform.

The Node-Red programming environment allowing for graphical programming was used to send data for visualization on the FESTO AX platform. With the help of appropriate nodes, it was possible to send basic information about the operation of the robot program, values of position, speed and torque of individual axes as well as information about the occurrence of anomalies to the platform.

The FESTO AX platform itself allows you to create assets, as well as subordinate objects with their own datapoints. In the case of the ongoing research project, the asset is the tripod, and the objects subject to it - the actuators of the mechanism, the datapoints of which are: position, speed and torque. In addition, the FESTO AX platform allows you to create error and warning messages, which was used to inform about the occurrence of an anomaly. For this purpose, it was necessary to define a variable and the condition which it has to satisfy so that a warning occurs. According to this condition, a warning should appear when the value of an anomaly exceeds a certain predetermined value.
MQTा Client

Publisher: Temperature Sensor

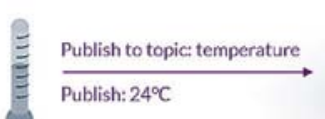

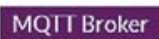

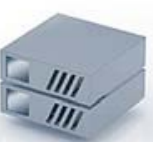

Publish: $24^{\circ} \mathrm{C}$

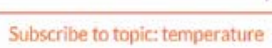

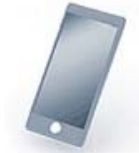

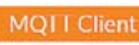
Subscriber: Mobile device Mobile device
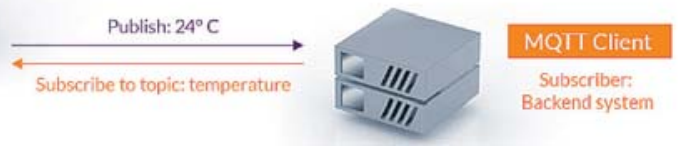

Fig. 11. Diagram of an example of how the MQTT protocol works Rys. 11. Schemat przykładowego działania protokołu MQTT (Message Queue Telemetry Transport) 


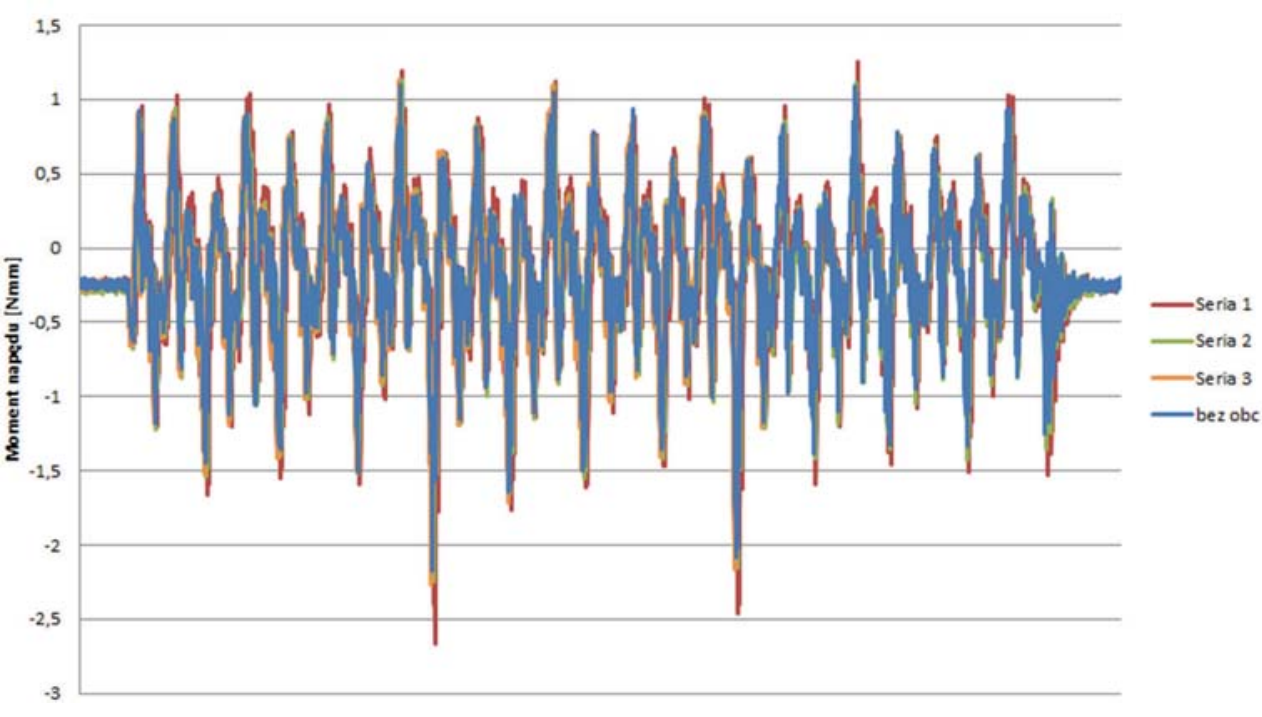

Fig. 12. Driving torque waveform during the execution of the robot program without load - black color and with load simulation - different colors

Rys. 12. Przebieg momentu napędowego przy wykonywaniu programu robotycznego bez obciążenia - kolor czarny oraz z symulowaniem obciążenia - inne kolory

The last of the options offered by the platform was the creation of a supervisory panel for a robotic position, the so-called dashboard, divided into tabs. This option allows you to display states, parameter values, and waveforms using the appropriate blocks.

In order to check the possibility of detection of anomalies in the operation of the tested stand by the Scraitec system, the results of measurements of the position, speed and driving torques of the tripod mechanism were collected during the execution of a single robot program call during normal operation of the robot.

Then, the wear of one of the guides of the tripod mechanism was simulated by using the structure described in chapter 2 , which was to be the result of the wear and tear of this element and an increase in its resistance to motion. In order to collect a representative sample of data, two full series of measurements were made, successively loading all actuator guides of the tripod mechanism, and data from three program calls without load were collected, which were used as training data to learn the tripod behavior model, responsible for detecting anomalies, and as control runs, checking if the model was not too fit to the training data.

During the preliminary analysis, it turned out that both the position value and the speed of movement of the actuator servo drives practically do not change depending on the simulated actuator loads - the motor drives almost perfectly compensate for the additional load so that it does not affect the trajectory of movement. It was therefore concluded that these signals (location and speed of movement) will not be transferred in subsequent experiments to the artificial intelligence model, as they are insignificant in terms of the information carried (Fig. 12).

Much more interesting, as expected, were the waveforms of the drive torques of the mechanism realized by the tripod actuators, e.g. when the actuator is loaded as A1, from which the data from the waveforms were first collected, a clear increase in the measured value can be seen. At lower speeds (60\% of the maximum dynamics), the increase took place for the entire mileage, for the higher ones ( $80 \%$ of the maximum dynamics), the increase was mainly related to the lower values of the torque achieved by the actuator motor A1.

It was also noted that even without additional load on the drives, successive measurement series of the torque values slightly differ from each other (as opposed to the practically identical waveforms of speed and position), which results from the need for the motor to compensate for system vibrations and internal motion resistance (friction) of the actuators themselves. (motion motors and gears). This makes teaching a model created in the Scraitec system to distinguish between standard deviations of signals resulting from the system mechanics itself from the often small deviations caused by artificial, simulated increase in resistance to motion, not a trivial task.

\section{The Artificial Intelligence Algorithm Used in the Test Stand}

Natural intelligence, defined in relation to the world of living creatures, is the ability to perceive, analyze and adapt to changes in the environment, as well as understand, learn and use the possessed knowledge. Created by John McCarthy in 1956, the term "artificial intelligence" (AI) was defined by Andreas Kaplan and Michael Haenlein as „the ability of a system to correctly interpret data from external sources, learn from them, and use that knowledge to perform specific tasks, and achieve goals through flexible adaptation". His colloquial, engineering understanding is simply the ability to learn or learn (someone) in relation to devices, machines and their systems - hence its other name as „machine intelligence” (MI).

The concept of teaching a virtual model developed by Scraitec uses the so-called $k$-means algorithm, also called $k$-Means Clustering algorithm. It allows for recursive division of the training input data set, which are readings from sensors with proper installation behavior, specifically e.g. normal operation of a robotic production stand, after prior standardization of patterns into disjoint clusters (subgroups) with the determination of their middle values, called landmarks. Then, in the thus created space, successive points are placed, corresponding to the current measurements, and their distance from the nearest landmark is measured. It is the input value to the sigmoid activation function, the output of which, ranging from zero to one, determines the probability of an anomaly score. This parameter was introduced in Scraitec as the final information about the possible occurrence of a potential anomaly, e.g. abnormal state, failure, etc., which can range from zero to one, where zero means normal work of the stand. Information on the state of successful behavior of the production stand ("global health") - is calculated as a complement to the value of one of the anomaly score.

The above-mentioned clustering is done so that the patterns in one cluster are similar to each other and differ from the patterns from another cluster. After collecting $n$ input data for grouping, the algorithm works as follows:

1. determining the number of $k$ clusters, which is often the most difficult task due to the fact that this parameter is often chosen ad hoc, and its incorrect selection may result in incorrect grouping of data, 


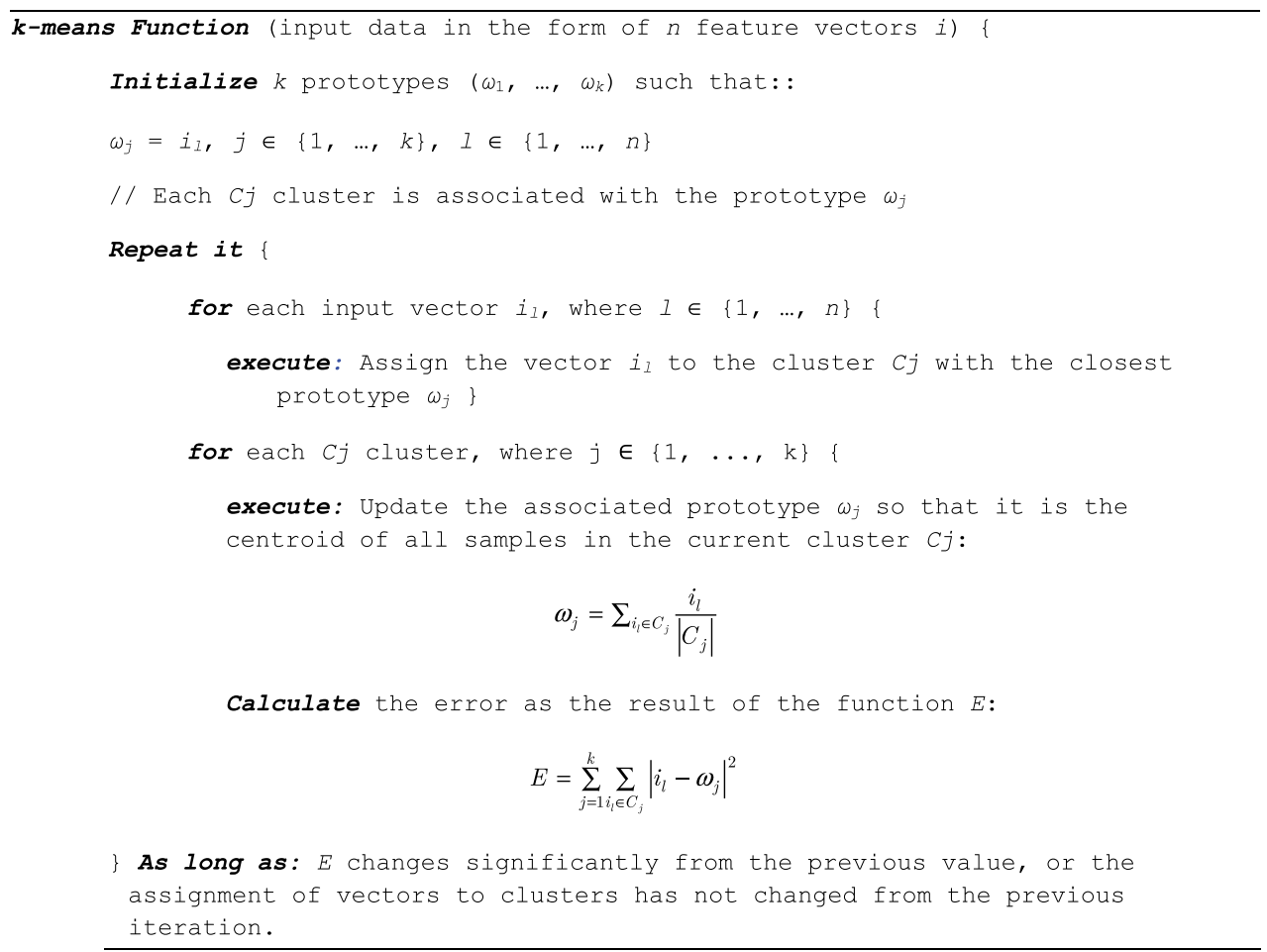

Fig. 13. Sample $k$-median algorithm pseudocode for singleloop execution of the clustering algorithm described in steps 2-7 Rys. 13. Przykładowy pseudokod algorytmu $k$-średnich dla wykonania pojedynczej pętli algorytmu klastrowania, opisanego w krokach 2-7
2. random selection of $k$ starting clusters from among $n$ input data,

3. measuring the distance of each of the remaining $(n-k)$ input data from the starting clusters and assigning it to the closest cluster,

4. calculation of a point being the average of the positions of all points belonging to a given cluster - determining the middle values of clusters, called centroid,

5. remeasure the distance of each input data, this time from the centroid of the clusters, and reassign it to the closest cluster,

6. calculation of the total variance of all clusters,

7. repeating steps $4-6$ until the value of the variance does not change significantly or the assignment of data to individual clusters stops changing,

8. repeating steps $2-7$ with a different selection of the initial positions of the clusters, after several iterations, selecting the assignment with the lowest variance (Fig. 13).

In the specific case of the project being implemented, a number of its parameters were selected to fit the model to the data, the most important of which, i.e. having the greatest impact on the behavior of the model are (Fig. 14):

- anomalySmoothness (in Polish gładkość anomalii) - the parameter responsible for the inertia with the rise and fall of the anomaly score value. Therefore, it allows you to change the anomaly signal from short jumps to a little changing signal with a relatively stable amplitude, which significantly facilitates the adjustment of the model - otherwise, even with high data consistency, a single measurement point could cause a large jump in the anomaly score value and thus send a notification about the possibility of the occurrence of an abnormal condition,

- dataNormalizationMode (in Polish wybór rodzaju normalizacji danych) - the parameter selecting the type of data normalization, the most commonly used algorithms in machine learning are available: $\mathrm{Z} \_$SCORE, MIN_MAX or CENTERING (normalization with the use of unit vectors),

- granularity (in Polish szczegótowość) - the parameter responsible for the number of landmarks created, in the case of using

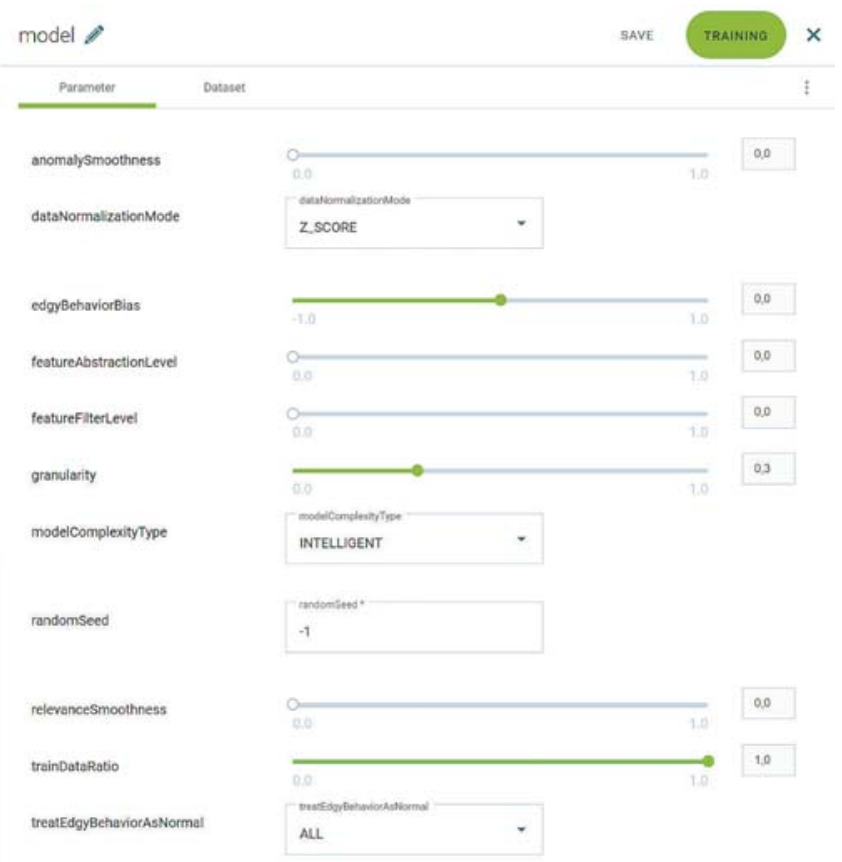

Fig. 14. Scraitec system window responsible for retrieving and setting the intensity of the model parameters values

Rys. 14. Okno systemu Scraitec odpowiedzialne za pobranie i nastawienie intensywności wartości parametrów modelu

the $k$-means algorithm also equal to the number of searched clusters. The values of the variable are between zero (which corresponds to the creation of ten focal points) and one (the creation of ten thousand points). The parameter should therefore be larger, the more complicated the input data waveforms, - modelComplexity Type (in Polish typ złożoności modelu) - the parameter specifying how the distribution of characteristic points in the feature space is performed. Two options are available:

- INTELLIGENT - landmarks placed using the $k$-means algorithm on points that are centroids of individual clusters, which ensures that they are in the center of point clusters, 
- $\boldsymbol{Q U I C K}$ - landmarks are placed randomly in the measurement space based on the entered randomSeed - the number used to initialize the pseudorandom number generator. Choosing the QUICK option is recommended only when the size of the data samples used is so large that the use of a computationally intensive k-means algorithm may not be recommended,

- treatEdgyBehaviourAsNormal (in Polish traktowanie zachowań brzegowych jako zachowań normalnych) - the parameter specifying the shape of the sigmoid curve used in the activation function, converting the distance between the input data and the characteristic points into an anomaly score. The variable has four values to choose from: ALL, MOST, SOME and LITTLE. The choice of each of them strongly changes the nature of the function, with ALL being the smoothest curve (so even large distances between the points will have little effect on the value of the anomaly degree), and LITTLE the sharpest (even very small deviations will be strongly detected),

- edgyBehaviorBias (in Polish btad zachowania brzegowego) - the parameter that allows a more precise adjustment of the curve used in the activation function (treatEdgyBehaviourAsNormal allows for a coarse selection of the curve shape). Variable values range from minus one to one, with negative values sharpening the curve and positive values smoothing it.

\section{The Results of Research on the Application of Al in the Test Stand}

\subsection{Abnormalities in the Behavior of a Single Component of the Test Stand}

The internal broker of the Scraitec-Data platform was used to present the results of the analysis, which made it possible to select the object from which the data is to be sent (e.g. a single automation actuator of the work stand, selected actuator of the robot used or the complete tripod mechanism in the test stand), and then selecting from these data information about the value of abnormal behavior of these selected objects and sending them to the platform using the AnomalyValue output block. A total of four such programs were created which corresponded to the three actuators of the tripod (A1, A2 and A3) and the fourth complete tripod mechanism (Fig. 15).

From the side of the Scraitec platform, we started with the picking of variable groups, for the visualization of the mechanism called „Tripod" and visualization of subgroups for each actuator in the Datapoints tab. The Festo Ax platform allowed for error messages and warnings regarding abnormalities. When adding a warning, it was necessary to define the variable and the condition of its occurrence. According to these data, the warning should appear when a given abnormality exceeds the set value.

In the tests described in this chapter, the analyzed components were servo drives and transmission gears of individual actuators of the tripod mechanism (A1, A2 and A3) (Fig. 16). For each actuator, successively, two series of measurements were carried out: without and with the attached element causing the increase of resistance to motion, simulating wear or abnormal condition of the guides of the actuaor carrier (e.g. after long use, dirty guides, etc.).

On the basis of preliminary analyzes, it was found that the position and velocity values do not change noticeably as a result of the applied change in the motion resistance (hereinafter referred to as the load) of the actuator, therefore the models on the Scraitec platform were learned only on the basis of the torque values of the actuator motors, without changing the resistance to motion (called referred to as no load) in the first series of measurements. The second series of measurements of the unloaded actuator was to correct the parameters of the model so that there was no overfitting and more effectively detect abnormal operating conditions. In this way, three models were created - individual for each actuator, which were tested in a series of measurements that already took into account their load.
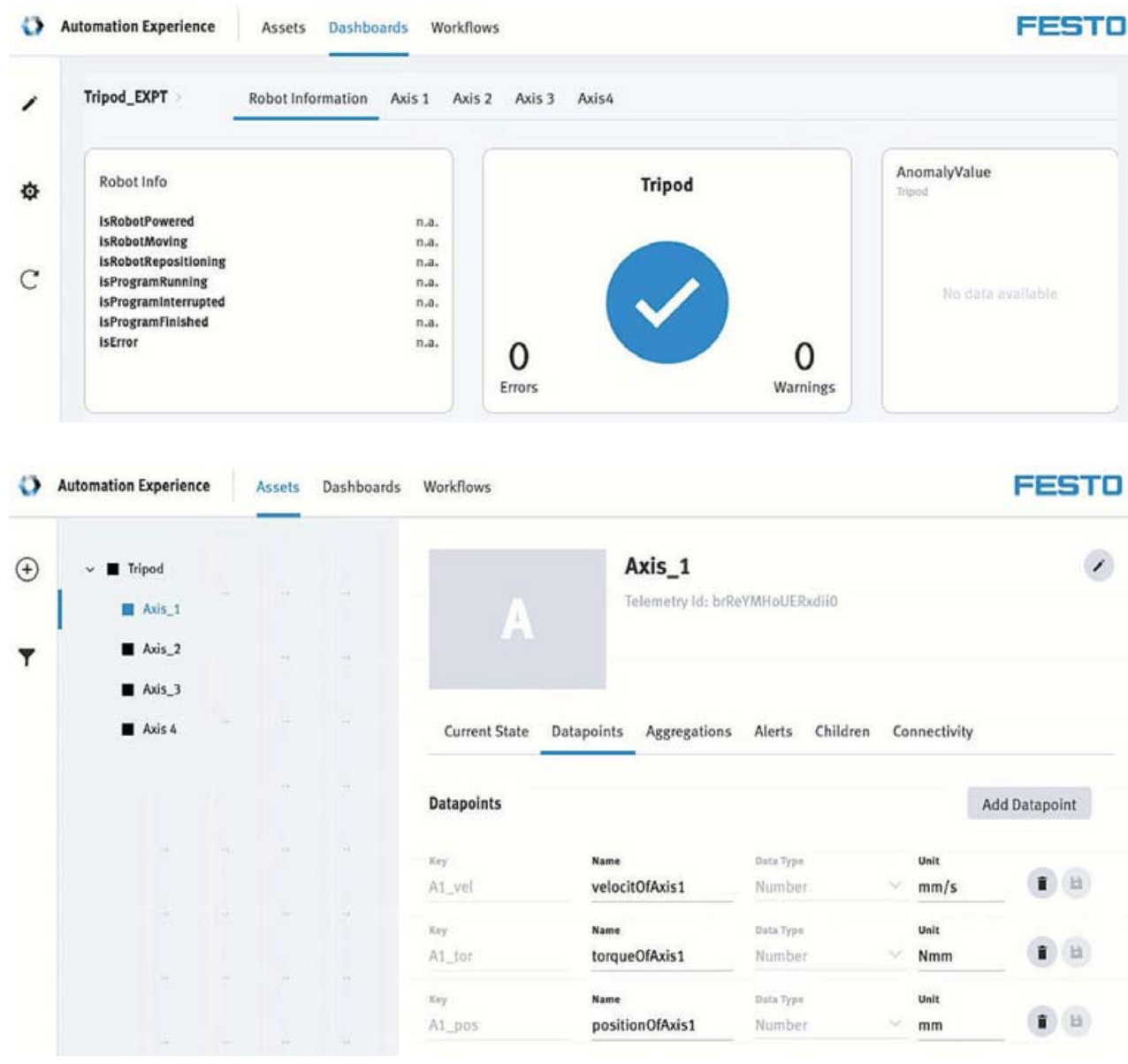

Workflows

FESTD

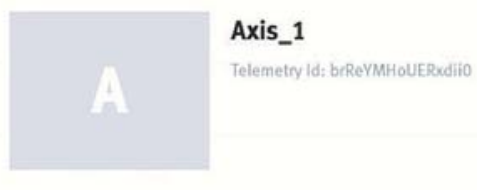

Current State Datapoints Aggregations Alerts Children Connectivity

Datapoints

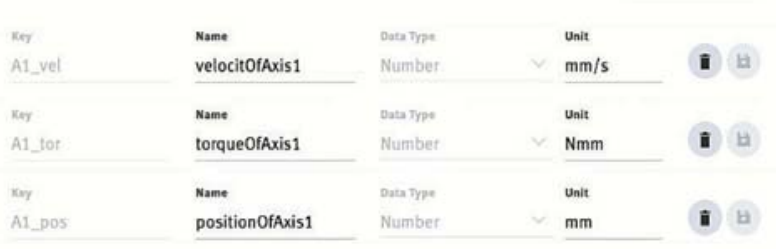

Fig. 15. The first tab of the panel supervising the test stand, containing information on the selection of the test object - in a specific case, it is the complete mechanism of the EXPT tripod used in the test stand Rys. 15. Pierwsza zakładka panelu nadzorującego badane stanowisko, zawierajaca informacje o wyborze obiektu badań - w konkretnym przypadku jest to kompletny mechanizm stosowanego $\mathrm{w}$ badanym stanowisku tripoda EXPT

Fig. 16. The supervisory panel tab containing information about the A1 actuator of the EXPT tripod, which robotizes the test stand Rys.16. Zakładka panelu nadzorującego zawierająca informacje o aktuatorze A1 tripoda EXPT robotyzującego badane stanowisko 
In the case of the $\mathrm{A} 1$ actuator, the occurring anomalies were not very clear, so it was decided to modify the model so as to emphasize as much as possible anomalies caused by an increase in resistance to motion (load) and to make them distinguishable from anomalies observed in no-load conditions during the second measurement series. For this purpose, the scope of behaviors treated as normal has been narrowed, as well as the granularity parameter has been increased and the value of the edgyBehawiorBias parameter decreased. These changes to the model meant that in the case of normal working conditions, when the moments are close to the values from the data set on the basis of which the model was learned, the anomalies could be considered negligible, while in the case of working conditions with a load resulting from increased resistance to motion, these anomaly parameters reached more pronounced values (Fig. 17).

In the case of the A2 actuator, large jumps in the anomaly values were observed, and therefore, in order to obtain the best possible model, the range of behaviors treated as normal was narrowed down, somewhat similar to the A1 actuator. The models were learned by increasing the value of the edgyBehawiorBias parameter from 0.0 (A1) to 0.45 (A2) in order to more effectively distinguish an anomaly caused by an increase in resistance to motion, from those without this load (Fig. 18).

For actuator A3 there were unexpected, in comparison with actuators A1 and A2, very low anomaly values, not exceeding ten percent of the AnomalyScore of both previously mentioned actuators (Fig. 19). In order to obtain the best possible compatibility of the model with the others, the scope of behaviors treated as normal has also been narrowed here. At the same time, the value of the granularity parameter was increased and the value of the edgyBehawiorBias parameter was reduced in order to more effectively distinguish anomalies caused by increased resistance to motion, from those without load.

In general, the presented results of the research on the components of the test stand can be characterized as follows:
- the combination of Festo's own proprietary control, monitoring and visualization platforms with the Scraitec platform confirmed the effectiveness of AI actions, identifying the occurrence of deviations from the normal operation of the robotic production stand, caused by the simulation of abnormal operation of selected components of this stand. The description of IT solutions implementing the mentioned connections of the programming platforms available in Festo is described in detail in [18],

- the described experiments have shown that the components, identical in their structure and operational and operational parameters, in the form of actuators used in the EXPT tripod test stand, behave clearly differently in terms of the identified anomaly score, under normal operating conditions and under operating conditions disturbed by the simulation of abnormal states. There may be at least several reasons for this. One of them may be the different degree of wear of individual actuators due to their previous use in the Application Center of Festo Polska. Another reason, e.g. the degree of wear or different settings of the structure simulating the increase in resistance to movement of the slide of the actuator gears,

- the selected model has a strong influence on the identification of normal and abnormal behaviors by selecting the intensity of the parameter values given in chapter 7 (Fig. 14). For example, increasing the granularity parameter to some extent improves the operation of the models, but too high a value of this parameter is also not favorable, as can be seen on the example of the driving torque waveform in actuator A1 (Fig. 17). Here, the anomalies reached very high values under working conditions with increasing resistance to motion, but they also appeared in the case of normal operating conditions of the actuator (Fig. 17a), on the basis of which this model was learned.

- it was also found that the experimentally identified anomalies changed quite rapidly throughout the measurement, a)

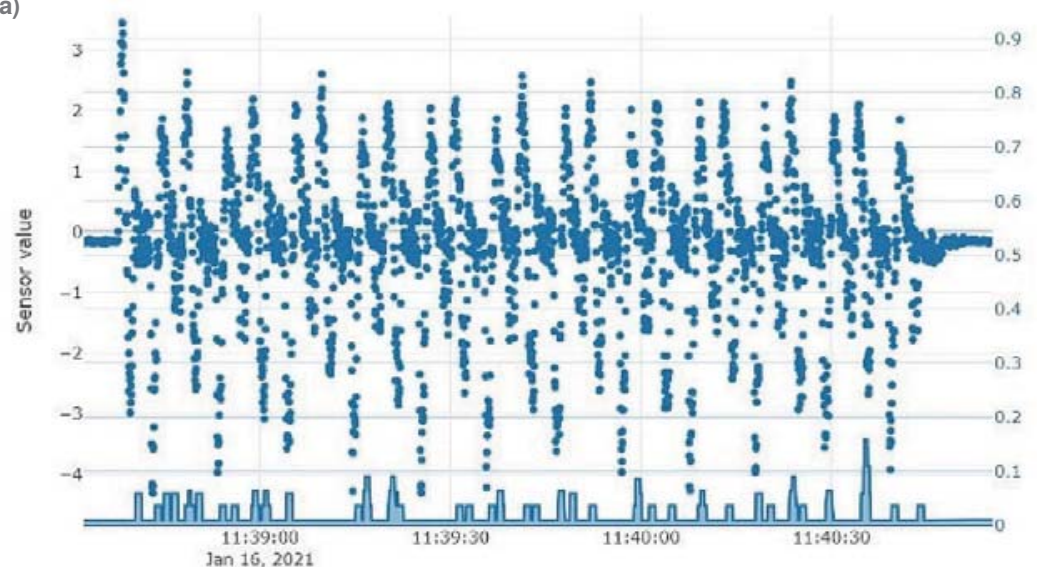

b)

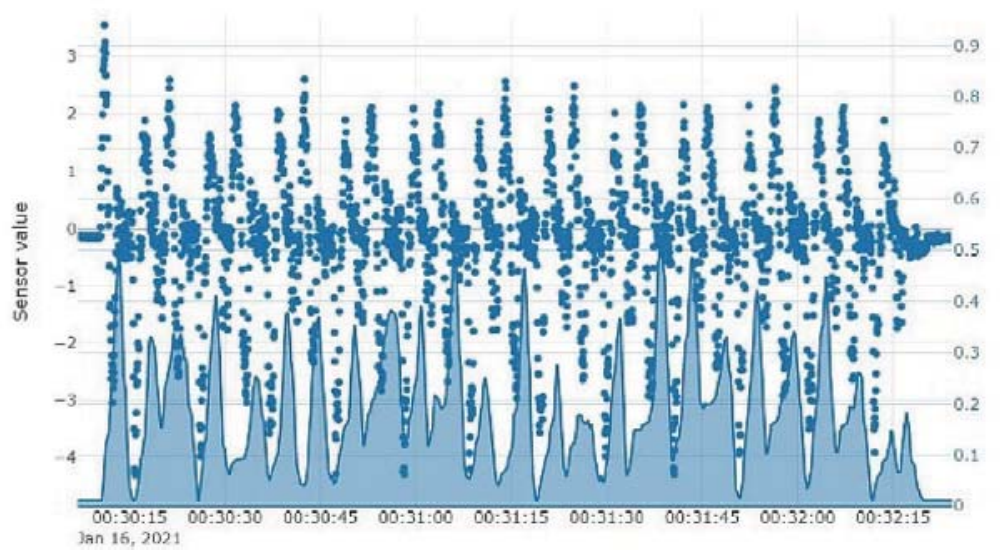

Fig. 17. Driving torque waveform and the abnormality value of the $\mathrm{A} 1$ tripod EXPT actuator for the robot dynamics equal to $80 \%$, obtained in the Scraitec system: a) without simulating the increase in motion resistance, b) with simulating the increase in motion resistance for the following model parameters: anomalySmoothness $=\mathbf{0 . 1}$, edgyBehaviorBias $=0.0$, granularity $=0.95$, treatEdgyBehaviorAsNormal $=$ MOST Rys. 17. Przebieg momentu napędowego i wartości anomalii aktuatora A1 tripoda EXPT, dla dynamiki robota równej $80 \%$, uzyskany w systemie Scraitec: a) bez symulacji wzrostu oporu ruchu, b) z symulacją wzrostu oporu ruchu dla następujących parametrów modelu: anomalySmoothness $=0,1$, edgyBehaviorBias $=0,0$, granularity $=0,95$, treatEdgyBehaviorAsNormal = MOST 
a)

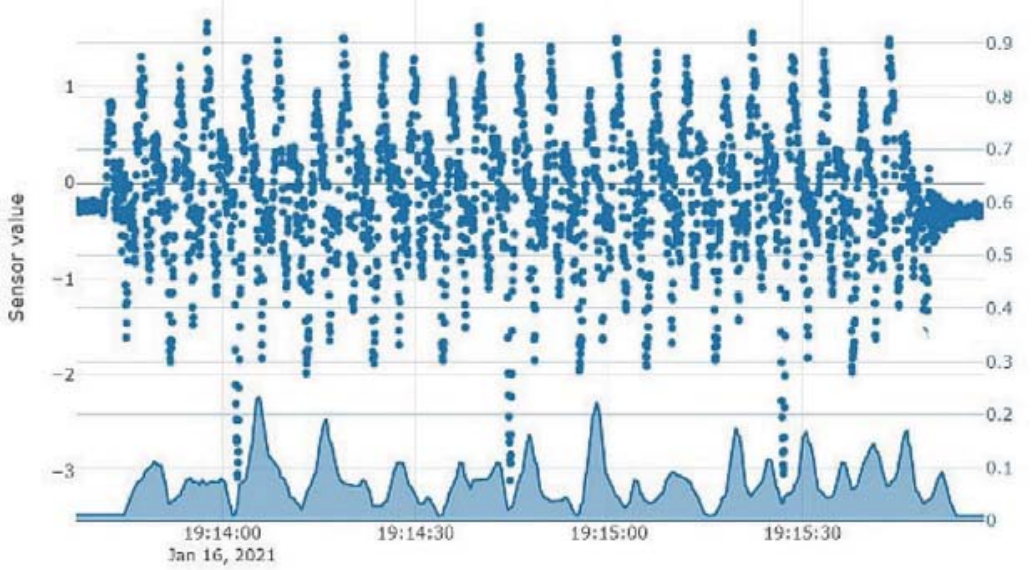

b)

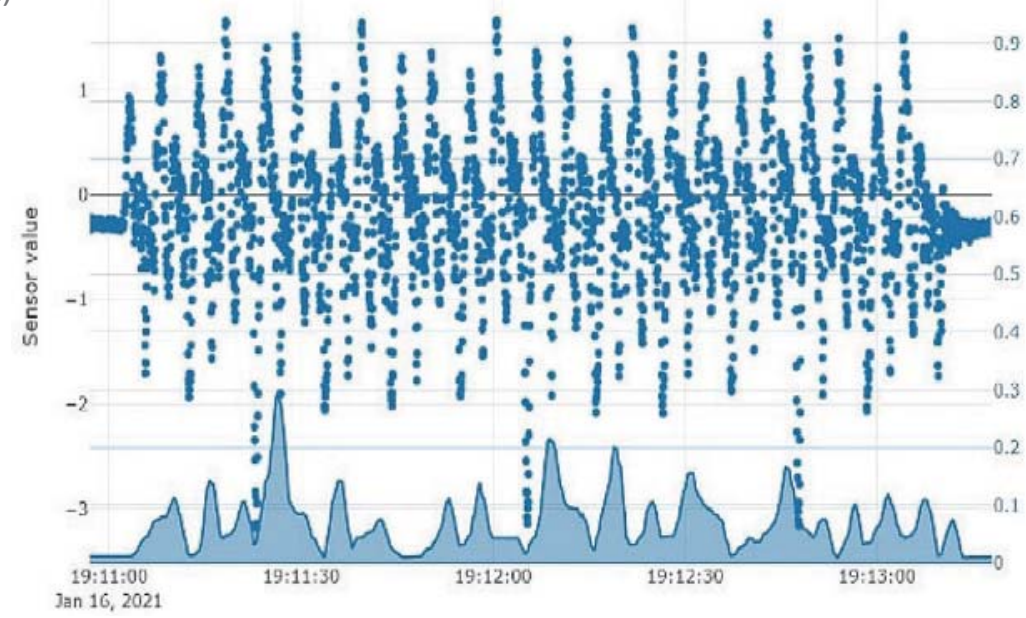

- Torque2(/topic) Fig. 18. Driving torque waveform and the abnormality value of the A2 tripod EXPT actuator for the robot dynamics equal to $80 \%$, obtained in the Scraitec system: a) without simulating the increase in motion resistance, b) with simulating the increase in motion resistance for the following model parameters: anomalySmoothness $=\mathbf{0 . 1 5}$ edgyBehaviorBias $=0.45$, granularity $=0.9$, treatEdgyBehaviorAsNormal $=$ MOST Rys. 18. Przebieg momentu napedowego i wartości anomalii aktuatora A2 tripoda EXPT, dla dynamiki robota równej $80 \%$, uzyskany w systemie Scraitec: a) bez symulacji wzrostu oporu ruchu, b) z symulacją wzrostu oporu ruchu dla następujących parametrów modelu: anomalySmoothness $=0.15$, edgyBehaviorBias $=0,45$, granularity $=0,9$, treatEdgyBehaviorAsNormal $=$ MOST which makes it difficult to assume which of them are true and which result from the inaccuracy of the model. It also turned out that increasing the value of the granularity parameter in the range from 0.6 to 0.9 , combined with decreasing the edgyBehawiorBias parameter, and improved the course of the anomaly score.

\subsection{Abnormalities of the Complete Test Stand}

Taking into account the non-trivial, ambiguous results of component research experiments (chapter 8.1), it was decided in the predictive diagnostics experiments of the robotic production stand to create an AI model which, instead of exercising separate control over each of the servo actuators of the mechanism, supervises the operation of the tripod stand, treating it as a completed one, an indivisible whole [18].

Such a solution, as opposed to considering each of the components separately, allowed for the predictive detection of the impending failure or the imminent wear state of the mechanism guides, manifested by even slight changes in the waveforms of several measured parameters, possibly omitted separately, but after cumulating allowing for the clear detection of the abovementioned anomalies.

Another advantage of such a cumulative approach is training a smaller number of models, and thus faster implementation of the AI system and clearer feedback, i.e. a smaller number of returned parameters.

The disadvantage of this approach seems to be more difficult than in the case of conducting separate analyzes to determine which specific component of the test stand is the cause of the alarm.

While testing the capabilities of the AI system to test the predictive diagnostic capabilities of a robotic complete production stand, a robotic program was performed for $80 \%$ and $60 \%$ of the maximum dynamics of the EXPT tripod mechanism. The measurements were made both in the simulation of failure, by increasing the load of one of the robot actuators, and in the normal, correct operation of the tripod, so as to be able to detect possible overfitting of the model, causing false warnings under normal operating conditions (Fig. 20, Fig. 21).

In order to avoid single, impulse jumps in the anomaly score value, which may result, for example, from measurement noise, which could signal the aforementioned false warnings, e.g. about the possibility of component wear, a small value of inertia was used in the rise and fall of the anomaly evaluation. As a result, the activation of warnings is associated with the persistence of a disturbing deviation in the measurement signal for a longer time or its appearance with a high frequency.

For the majority of runs made with $80 \%$ of the maximum dynamics of the robot's movement, it was possible to obtain well-distinguishable differences in the anomaly score values between runs with a simulated load and runs without this load.

The amplitudes of detected anomalies are relatively small, which caused problems with determining the threshold value, beyond which an alarm warning would be issued. over-fitting of the model. Increasing the AI-detected one is not a trivial task - increasing the algorithm's penalties for the distance of points from landmark measurements from clustered landmarks can easily over-fit the AI model.

In the conducted experiments, after performing predictive diagnostics of the robotic production stand, for the measurement values related to $80 \%$ of the maximum dynamics of the tripod mechanism movement, analogous tests were performed for $60 \%$ of the dynamics of the mechanism movement (Fig. 22, Fig. 23). 
a)

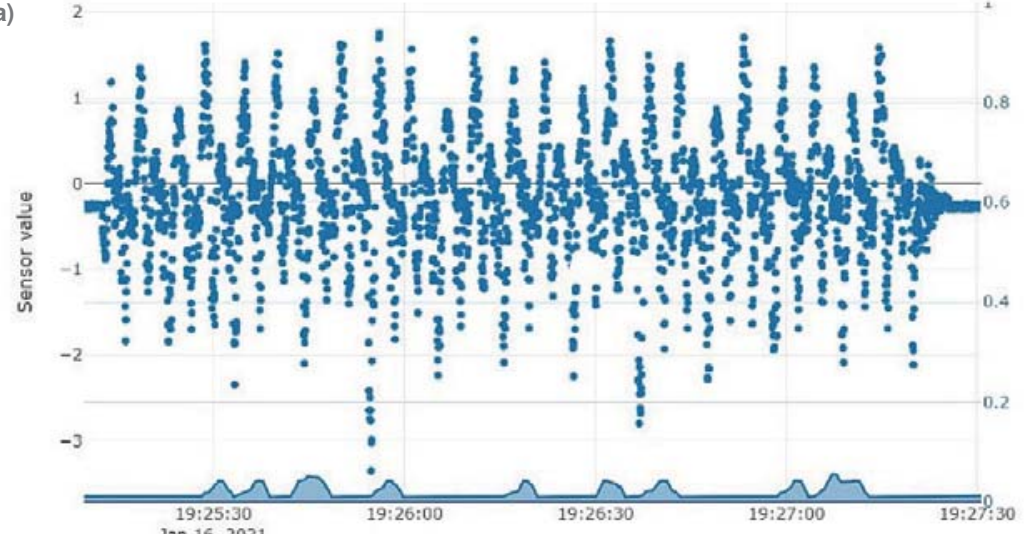

b)

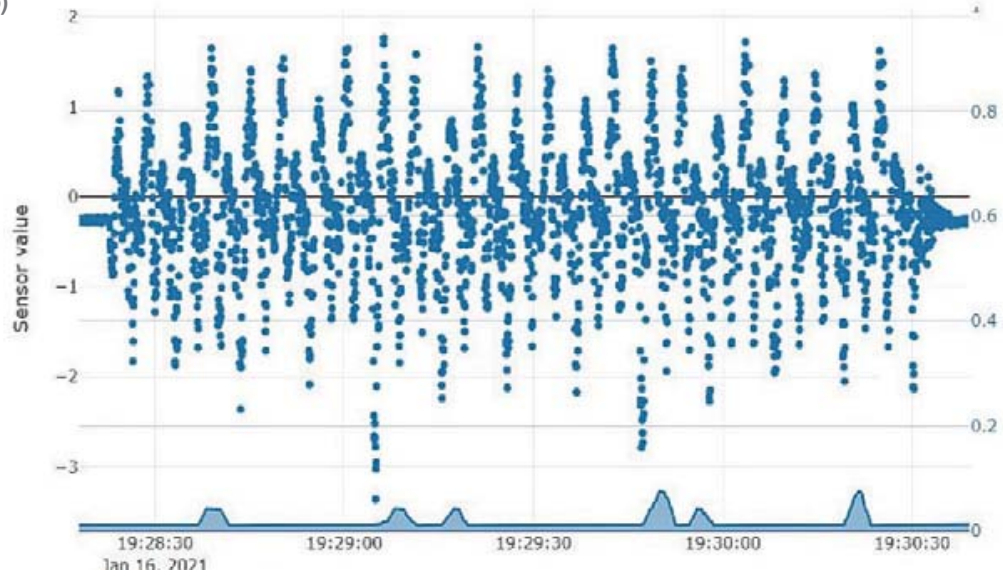

- Torque3(/topic) - AnomalyScore
Fig. 19. Driving torque waveform and the abnormality value of the A3 tripod EXPT actuator for the robot dynamics equal to $80 \%$, obtained in the Scraitec system:

a) without simulating the increase in motion resistance,

b) with simulating the increase in motion resistance for the following model parameters: anomalySmoothness $=0.15$, edgyBehaviorBias $=0.45$, granularity $=0.9$,

treatEdgyBehaviorAsNormal $=$ MOST Rys. 19. Przebieg momentu napędowego i wartości anomalii aktuatora A3 tripoda EXPT, dla dynamiki robota równej $80 \%$, uzyskany w systemie Scraitec: a) bez symulacji wzrostu oporu ruchu, b) z symulacją wzrostu oporu ruchu dla następujących parametrów modelu: anomalySmoothness $=0.15$, edgyBehaviorBias $=0,45$, granularity $=0,9$ treatEdgyBehaviorAsNormal $=$ MOST
The results of these experiments turned out to be similar to the previously performed experiments with higher dynamics of the tripod mechanism movement, but it was possible to obtain higher values of anomaly score amplitudes during the occurrence of simulated wear of the tripod actuator guides. This is due to the fact that the AI model with higher values of parameters responsible for the detection of anomalies was used, which turned out to be possible thanks to obtaining a greater ratio of the resistance values of actuator sliders to the analogous values related to the movement of the mechanism with lower dynamics of movement.

For higher values of motion dynamics, the torque generated by the actuator motors, which translates into the acceleration of the sliders moving along the guide rails, must naturally be higher to implement the programmed speed ramps. This makes the load, which does not change significantly with the speed of movement, generated by the mechanical structure rubbing against the guides, less significant compared to the values of the torque of the motors needed to execute the robot program without the load of the movement of the sliders.

It was noticed that for the measurements performed with both the tripod actuator movement dynamics used in the experiments, a significant difficulty in the appropriate adjustment of the AI model turned out to be the slight variance of moment signals, noticed during the initial analysis of the anomaly score, occurring during subsequent executions of the robotic program, resulting from variable courses of friction values and vibrations of the structure itself, forcing this friction (frictional vibrations). Since the torque deviation of the actuator motors obtained by increasing the axle load was relatively small, this variance made anomaly detection for the raw sensor data in these series problematic. It often forced an overfitting of the AI model.

Therefore, it was decided to additionally apply low-pass filtering of measurement signals, thanks to which it was possible to partially eliminate the high-frequency noise of measurement signals generated by the torque sensors of actuator motors.

No-load waveforms for $80 \%$ of the maximum dynamics of tripod behavior
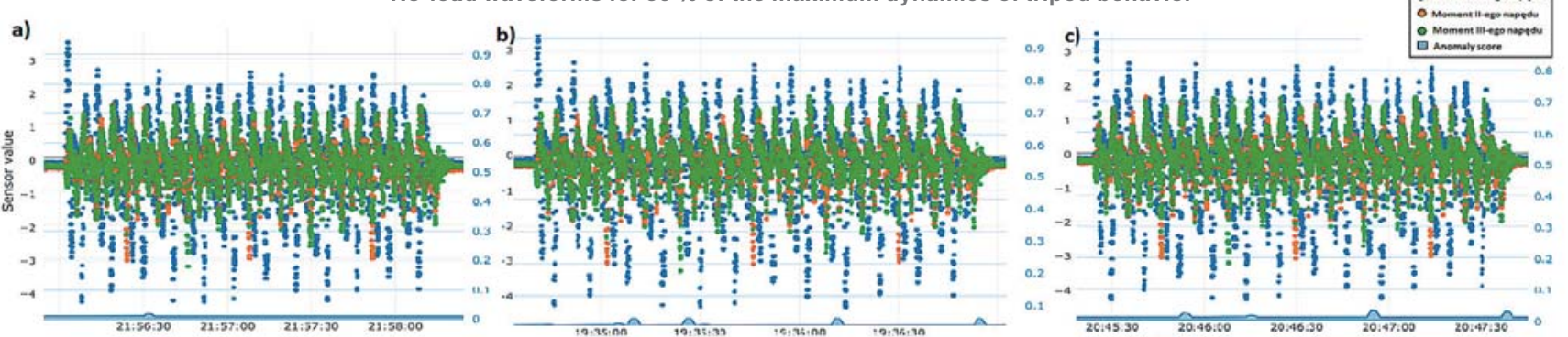

Fig. 20. Diagnostics results without load of EXPT tripod actuators due to the increase of resistance to motion:

a) first measurement series; b) second measurement series; c) third measurement series. Anomaly score - the course of the value at the very bottom of the chart is practically zero, so the Al system does not correctly detect abnormal tripod behavior

Rys. 20. Wyniki diagnostyki bez obciążenia aktuatorów tripoda EXPT wzrostem oporów ruchu: a) pierwsza seria pomiarowa; b) druga seria pomiarowa; c) trzecia seria pomiarowa; Anomaly score - przebieg wartości na samym dole wykresu jest praktycznie zerowy, a więc system Al prawidłowo nie wykrywa anormalnych zachowań tripoda 

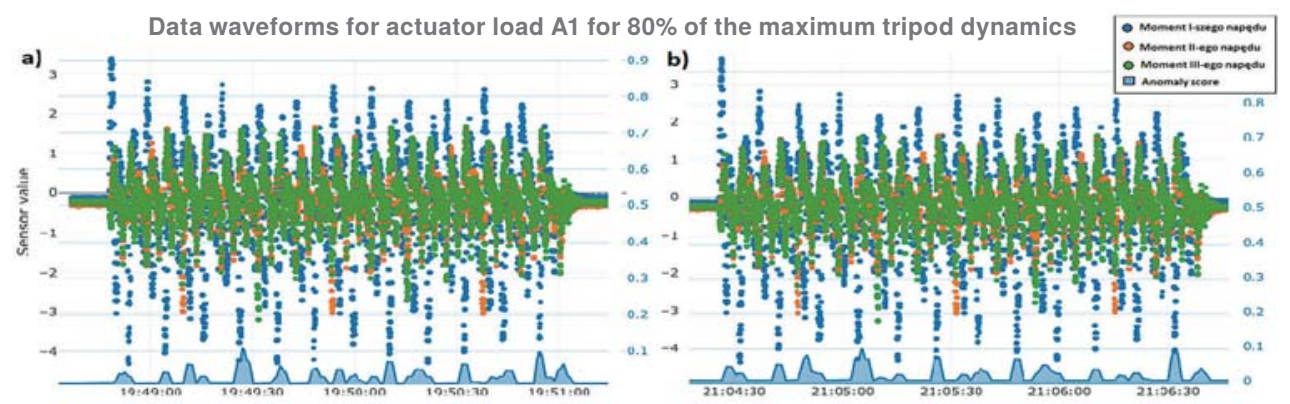

Fig. 21. Diagnostics results with load of EXPT actuators A1 due to the increase in resistance motion: a) first measurement series; b) second measurement series. Anomaly score - the value runs at the very bottom of the chart are significantly different from the runs without load, but are characterized by low amplitude values

Rys. 21. Wyniki diagnostyki z obciążeniem aktuatora A1 tripoda EXPT wzrostem oporów ruchu: a) pierwsza seria pomiarowa; b) druga seria pomiarowa. Anomaly score - przebiegi wartości na samym dole wykresu znacząco różnią się od przebiegów bez obciążenia, ale charakteryzują się niewielkimi wartościami swej amplitudy

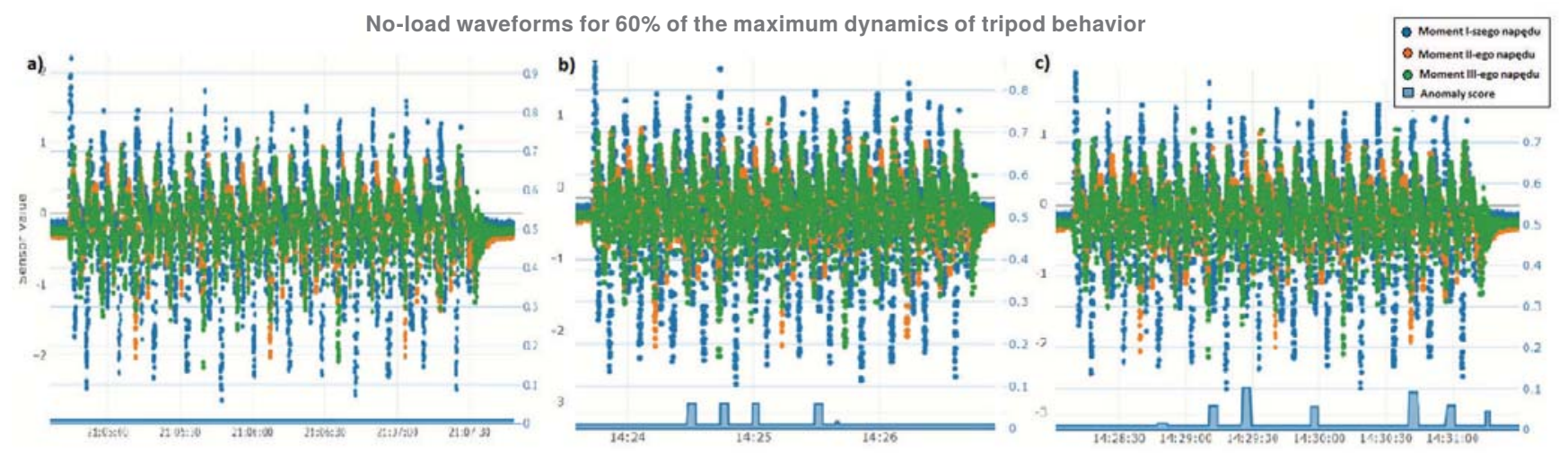

Fig. 22. Diagnostic results without EXPT tripod load due to the increase in motion resistance: a) the first measurement series, b) the second measurement series, c) the third measurement series: Anomaly score - the course of the value at the very bottom of chart, also for $60 \%$ of the maximum tripod dynamics there was no excessive adjustment of the model, anomaly score are rare and close to zero

Rys. 22. Wyniki diagnostyki bez obciążenia tripoda EXPT wzrostem oporów ruchu: a) pierwsza seria pomiarowa, b) druga seria pomiarowa, c) trzecia seria pomiarowa: Anomaly score - przebieg wartości na samym dole, również dla $60 \%$ maksymalnej dynamiki tripoda nie nastąpiło nadmierne dopasowanie modelu, wartości anomaly score występują rzadko i są bliskie zeru

In the Scraitec system, it is possible to filter the data in the AI model itself, but the unknown impact of the available filter parameters prompted the use of well-documented averaging filters in the conducted experiments, as part of the initial signal processing, when sending them from the controller in the control cabinet to the diagnostic system (Fig. 24).

The use of signal filtration significantly improved the detection of anomalies when conducting predictive diagnostics for the case of $60 \%$ of the maximum dynamics of the tripod motion, significantly increasing the amplitudes of the ano- maly score appearing when simulating the frictional loads of the actuators.

It was possible to obtain an AI model which, when the alarm warning threshold is set to one tenth of the maximum value of the anomaly score, correctly issues notifications about the possibility of abnormal conditions in the test stand, in more than nine out of ten cases, even with relatively small deviations in its value.

Slightly worse results were obtained when filtering the data for measurements made at $80 \%$ dynamics of the tripod mecha-

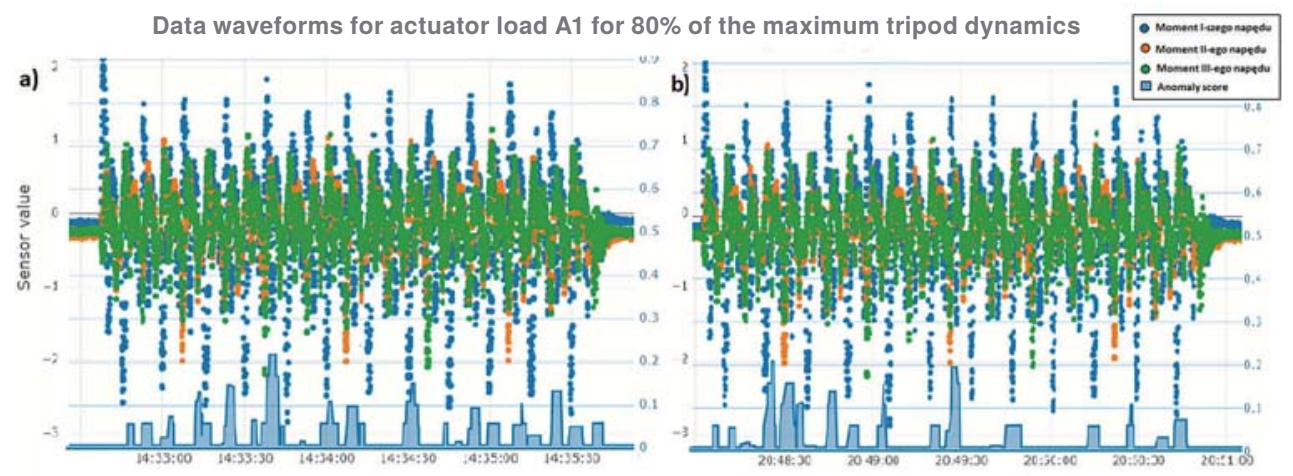

Fig. 23. Diagnostic results with the load of the A1 actuator EXPT tripod with an increase in resistance to motion: a) first measurement series; b) second measurement series. Anomaly score - the waveforms of the values at the bottom of the graph are higher than for the load of $80 \%$ of the dynamics of robot program execution, however, good model adjustment is still relatively difficult, but the waveforms differ significantly from the runs without load

Rys. 23. Wyniki diagnostyki z obciążeniem aktuatora A1 tripoda EXPT wzrostem oporów ruchu: a) pierwsza seria pomiarowa; b) druga seria pomiarowa. Anomaly score - przebiegi wartości na samym dole wykresu są wyższe niż dla obciążenia $80 \%$ dynamiki wykonywania programu robotycznego, jednak dobre dopasowanie modelu jest nadal stosunkowo trudne, jednak przebiegi znacząco różnią się od przebiegów bez obciążenia 


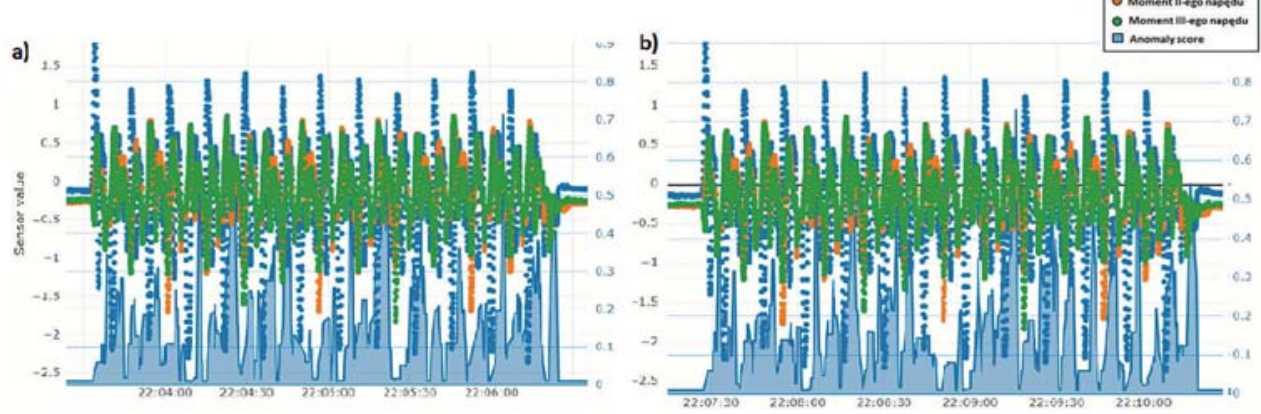

Fig. 24. Diagnostics results with the load of the A1 actuator EXPT tripod, an increase in resistance to motion and additional low-pass filtering of signals: a) the first measurement series; b) the second measurement series. Anomaly score - the waveforms of values at the bottom of the graph are very high when anomalies occur, which makes it easier to set alarms that indicate a clear wear of the stand components, also the occurrence of emergency

Rys. 24. Wyniki diagnostyki z obciążeniem aktuatora A1 tripoda EXPT wzrostem oporów ruchu oraz z dodatkową filtracją dolnoprzepustową sygnałów: a) pierwsza seria pomiarowa; b) druga seria pomiarowa. Anomaly score - przebiegi wartości na samym dole wykresu są bardzo wysokie przy występowaniu anomalii, co ułatwia ustawienie alarmów, sygnalizujących wyraźne zużycie elementów stanowiska, także wystąpienie stanów awaryjnych

nism movement, which results from the previously described AI behavior, but also for this dynamics of movements, the predictive diagnostics of the robotic production stand was at a relatively good level.

In conclusion, by applying the approach based on treating the tripod as a whole and fitting the AI model to all three signals generated by the torque sensors of the servo motors of the tripod actuators, it was possible to obtain in both cases of loads and for both considered dynamics of motion quite good anomaly discrimination. This allows the conclusion that the created AI system quite effectively warns about the actual wear of the tripod's mechanical elements, invisible directly from the physical course of this information in time.

\section{Conclusions}

The development of an application ensuring predictive diagnostics of a robotic stand turned out to be a complex task, requiring knowledge of the robot's operation itself, the ability to write robotic programs, implementation of communication between individual applications and knowledge of machine learning issues. By overcoming these difficulties, it was possible to build a system that uses AI for the correct identification of abnormal or emergency states in a robotic production stand.

Attempts to analyze data using a model with regard to individual components of the robot's mechanism, such as its actuators, led to the non-trivial conclusion that obtaining a system capable of detecting anomalies is possible, but requiring a large number of measurements to select a model that could effectively extract component behavior deviating from normal. For the correct and effective operation of predictive diagnostics, in this case, the data set for model training should be significantly enlarged by further measurement points for normal working conditions,

By conducting data analysis with the use of a model treating the tripod mechanism with all its actuators as a whole, it was possible to obtain a system ensuring effective diagnostics of its behavior, detecting even quite minor irregularities in its operation, caused e.g. by worn out mechanical elements of the mechanism structure. The analyzes were carried out by training the models during the execution of the motion program, for the different dynamic behavior of the mechanism. In the future, one could try to detect anomalies even with any dynamics, using the data normalization mechanisms to design the model.

Continuing the development work of the developed system, a better simulation of the occurring failures could also be used: in the described version it was only a structure increasing fric- tion during actuator operation. You can also try to diagnose components that have suffered actual damage during the operation of the stand, so as to better understand what deviations in the values of the generated signals the model should be particularly sensitive to.

The Scraitec system turned out to be a convenient tool for creating models, performing diagnostics and data supervision, but it also has many limitations related to the fairly early phase of the development cycle (during the research project, the latest, experimental version of the system, provided by Resolto was used) and problems with the stability of the operation that would have to be resolved before its large-scale introduction into real industrial sites. It would also be worth considering enriching it with machine learning algorithms that allow for automatic detection of useful information and the creation of feature vectors from it and then fed to the model. This would greatly facilitate the work of the modeling operator, especially for more kinematically complex mechanisms, e.g. using already existing techniques called Sparse Filtering to create unsupervised feature learning algorithms from raw sensor data.

One of the more obvious stages of the development of the constructed solution would be the replacement of the industrial computer used to host applications responsible for visualization and data supervision, with a cloud application with which the robotic controller, located in the control cabinet, would connect via the IIoT Gateway, which would allow access to the results of diagnostics from any device with Internet access.

Such a solution would be included in the area of intelligent production, decisive for the success of Industrial Transformation 4.0, assuming computerization and internetization of production processes. The combination of an industrial computer enabling remote control and diagnosis of processes with an intelligent production system using an AI algorithm would result in the creation of a solution that would be able to predict anomalies and failures predictably, and thus effectively extend the operation time of devices, machines or even the entire production line.

\section{References}

1. Olszewski M., Mechatronizacja produktu i produkcji-przemyst 4.0 (Mechatronization of the Product and the Production - Industry 4.0). „Pomiary Automatyka Robotyka”, Vol. 20, No. 3, 2016, 6-28, DOI: 10.14313/PAR_221/13.

2. Kaliczyńska M., Kluczowe technologie Przemysłu 4.0 (Key Technologies of Industry 4.0). „Automatyka”, Nr 1-2, 2018, 95-96. 
3. Olszewski, M., Mechatronika (Mechatronics). „Automatyka", Nr 1-2, 2018, 97-99.

4. Olszewski, M., Przemyst 4.0 (Industry 4.0). "Automatyka”, Nr 1-2, 2018, 99-104.

5. Bord of Management, Messe München GmbH: automatica, Optimize your Production. Face the Future of Manufacturing. Final Edition 2018, [www.automatica-munich.com].

6. Robotik und Production, Integration, Anwendung, Lösungen. [In:] Highlights der automatica, Vol. 3, No. 3, TeDo Verlag GmbH, Marburg (2018).

7. Olszewski M., automatica 2018. Optimize your Production. „Automatyka”, Nr 10, 2018, 109-124.

8. Piątek Z., Collaborative and Mobile Robots. AGV Report from the Market. APA - Automatyka Podzespoły Aplikacje, Reports 2019.

9. Olszewski M,: Wspótczesna robotyka (Modern Robotics), Part III, Essay Robotics. „Automatyka”, Nr 9, 2019, 89-107.

10. Poreda R., Gracel J., The Introduction of Robotics. Six Common Mistakes. „Automatyka”, Nr 3, 2019, 40-42.

11. Staniszewska, A., Zrobotyzowany przemyst (The Robotised Industry). „Automatyka”, Nr 3, 2019, 89-107.

12. Olszewski M., Modern Industrial Robotics. „Pomiary Automatyka Robotyka", Vol. 24, No. 1, 2020, 5-20, DOI: $10.14313 /$ PAR_235/5.

13. Grzebień S., System nadzorujacy stanowisko produkcyjne $w$ przemyśle 4.0 (A System for Supervising a Production Stand in Iindustry 4.0). MSc thesis (Promoter M. Olszewski). Warsaw University of Technology, 2017.

14. Gajewski P.M., Rozwiazania wybranych problemów informatycznych w projektach racjonalizacji technicznej procesów produkcyjnych przygotowania powierzchni prowadzonych $w$ firmie SciTeeX (Solutions of Selected IT Problems in Projects of Technical Rationalization of Production Processes of Surface Preparation Carried out at SciTeeX). BSc thesis (Promoter M. Olszewski). Warsaw University of Technology, 2018.

15. Kwiatkowski P.K., Zrobotyzowana mobilna stacja paletyzujaca z robotem wspótpracujacym (Robotized, Mobile Pallatization Stand Based on Collaborative Robot). MSc thesis (Promoter M. Olszewski, work awarded in the Competition "Young Innovations", PIAP, in 2019 and by Siemens and the Rector of Warsaw University of Technology, in 2019). Warsaw University of Technology, 2019.

16. Karpowicz N.A., Jacyniuk M.T., Projekt pneumotronicznego robota portalowego z serwopozycjonowaniem realizowanym przez wyspe zaworowa Festo Motion Terminal (Design of a Pneumotronic Portal Robot with Servo Positioning by the Valve Isle Festo Motion Terminal). BSc thesis (Promoter M. Olszewski). Warsaw University of Technology, 2020.

17. Trocki D., Opracowanie sterowania ręcznego oraz zrobotyzowanego stanowiska lakierniczego (Development of Manual Control and Robotic Painting Stand). MSc thesis (Promoter M. Olszewski, work awarded by Siemens and the Rector of Warsaw University of Technology, in 2020). Warsaw University of Technology, 2020.

18. Mazur M., Wojciechowski A.P., Implementacja komunikacji oraz nadzoru danych przy użyciu metod sztucznej inteligencji dla robota wielołańcuchowego - tripoda EXPT (Implementation of Communication and Data Supervision Using Artificial Intelligence Methods for a Multi-Chain Robot-Ttripod EXPT). BSc thesis (Promoter M. Olszewski), Warsaw University of Technology, 2021.

19. Panasiuk J., Kaczmarek W., Robotyzacja procesów produkcyjnych (Robotization of Production Processes). PWN, Warszawa 2017.
20. Stumm S., Braumann J., von Hilchen M., Brell-Cokcan S., On-site Robotic Construction Assistance for Assembly Using a-priori Knowledge and Human-Robot Collaboration. [In:] Rodić A., Boranglu T. (eds), Advances in Robot Design and Intelligent Control, Vol. 540, Springer 2017.

21. Pilz T., Neue Wege in der Robotik beschreiten. Robotik und Produktion. Integration, Anwendung, Lösungen, 3, 2018, 8-10.

22. Merlet J.P., Solving the Forward Kinematics of a Goughtype Parallel Manipulator with Interval Analysis. "International Journal of Robotics Research", Vol. 23, 2004, 221-235, DOI: 10.1177/0278364904039806.

23. Zhang D., Parallel Robotic Machine Tools. Springer, New York, Heidelberg 2010.

24. Stoll W., Bionik. Lernen von der Natur - Impulse für Innovation. Edition Festo, Esslingen 2018.

25. Easki P.A., Kinematic Analysis of Parallel Manipulators. Publisher Politechnika Świętokrzyska, M121, Kielce 2019.

26. Olszewski M., Elektryczne napędy $i$ serwonapędy siłownikowe (Electric Drives and Servo Motors). „Automatyka", Nr 1-2, 2020, 106-110.

27. www.vxchnge.com/blog/iot-statistics.

28. www.astor.com.pl, Wydawnictwa ASTOR.

29. www.automatica-munich.com - Bord of Management, Messe München $\mathrm{GmbH}$.

30. www.vxchnge.com/blog/iot-statistics - Gyarmathy K., Comprehensive Guide to IoT Statistics You Need to Know in 2020.

31. www.scraitec.com/en/applications/predictive-maintenance/ - Scraitec, predictive maintenance.

32. www.scraitec.com/ - Scraitec.

33. www.elunic.com/en/predictive-maintenance/ - Elunic, predictive maintenance.

34. www.elunic.com/en/shopfloor-io/ - Elunic, shopfloor-io,

35. https://c3.ai/ - C3.ai.

36. https://erium.de/loesungen/\#erium-managment - Erium.

37. www.festo.com $/ \mathrm{cms} / \mathrm{pl} \_$pl/16520.htm - Festo.

38. www.festo.com/cat/en-gb_gb/data/doc_ENGB/PDF/ EN/EXPT_EN.PDF - Documentation of the Manipulator from Series Tripod EXPT, Festo.

39. www.festo.com/cat/en-gb_gb/data/doc_engb/PDF/EN/ DGE-ZR EN.PDF - Drive Dokumentation DGE, Festo.

40. www.festo.com/media/pim/252/D15000100122252.PDF Serwo Motor Dokumentation EMMS-AS, Festo.

41. www.keba.com/download/x/6f7f955268/keba_kecontrol keconnect_c5_product_catalogue.pdf - Control Data Shit C5, KEBA.

42. www.festo.com/cat/pl_pl/data/doc_ENGB/PDF/EN/ CMMT-AS_EN.PDF - Serwo Drive CMMT-AS, Festo.

43. www.keba.com/file/downloads/industrial-automation/ data-sheets/KeTop_T70_Datenblatt_web.pdf - Dokumentation of the Operator Panel KeTop, KEBA.

44. www.balena.io/docs/reference/OS/overview/2.x/ - BalenaOS,

45. www.hilscher.com/products/product-groups/industrial-internet-industry-40/netiotnetfield-edge/niot-e-tijcx-gb-reeis/ - Industrial Computer.

46. www.rtautomation.com/technologies/opcua - OPC UA.

47. www.rtautomation.com/industrial-networking/modbus/modbus-as-a-data-transport-over-opc-ua - Modbus, OPC UA.

48. https://mqtt.org - MQTT Broker. 


\section{Sztuczna inteligencja w poszukiwaniu stanów anormalnych w zrobotyzowanym stanowisku produkcyjnym}

Streszczenie: Celem opisywanych badań jest inżynierskie rozwiązanie problemu implementacji metod sztucznej inteligencji do poszukiwania stanów anormalnych, skrajnie awaryjnych, w zrobotyzowanych stanowiskach produkcyjnych. Zadanie to wynika z potrzeby poprawy niezawodności eksploatacyjnej zautomatyzowanych i zrobotyzowanych linii produkcyjnych, a tym samym racjonalizacji wartości użytkowej i kosztowej tych linii. Opisano dostępne rozwiązania sprzętowe oraz istniejące i nowo wprowadzane nowe procedury i platformy informatyczne. W części sprzętowej prac wykorzystano robota z mechanizmem trójłańcuchowym, z elektrycznymi serwonapędami przekładniowymi, skonfigurowany za pomocą oprogramowania Festo Automation Suite, zaprogramowany za pomocą sterownika KEBA oraz opracowanego programu aplikacyjnego KeStudio.

Słowa kluczowe: robotyzacja, stanowisko produkcyjne, sztuczna inteligencja, przewidywanie stanów nienormalnych

\section{Grzegorz Bojarczuk, MSc, Eng}

grzegorz.bojarczuk@festo.com

In 2017, he graduated from the Faculty of Elec trical Engineering at the Warsaw University of Technology. Currently, the Team Leader of the Festo Polska Application Center responsible for application tests of industrial applications. Additionally, as a Digital Business Driver, he deals with the subject of digital trends changing industrial production.

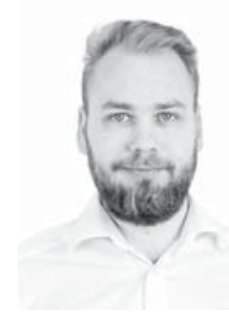

Miłosz Mazur, BSc, Eng

miloszmazurbe@gmail.com

ORCID: 0000-0002-7737-2342

A student of the second degree studies at the Faculty of Mechatronics of the Warsaw University of Technology in the field of Automatic Control, Robotics and Industrial Computer Science, he graduated with honors from the first degree studies also at the Faculty of Mechatronics, receiving the title of Robotics Engineer

(2021), completed an internship at ASTEK Polska Sp. z 0.o., where he worked as a web technology developer (2020), co-author of the thesis carried out in cooperation with the Application Center FESTO Sp. z 0.0. under the title "Implementation of communication and data supervision using artificial intelligence methods for a robotic stand" defended with the 5th grade.

\section{Prof. Mariusz Olszewski, PhD, DSc}

\section{Aleksander Piotr Wojciechowski, BSc, Eng} a.wojicechowski100@gmail.com

Second-cycle student at the Faculty of Mechatronics of the Warsaw University of Technology in the field of Automatic Control, Robotics and Industrial Computer Science, robotics engineer (Warsaw University of Technology, 2021), as an apprentice at Astor Sp. z 0.0. worked on the integration and simulation of a flexible palletizing stand (2020), co-author of the thesis carried out with the Application Center FESTO Sp. z o.0. "Implementation of communication and data supervision using artificial intelligence methods for a robotic position" defended with the 5 th grade

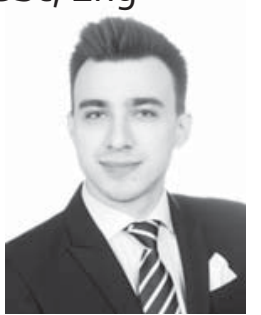

ORCID: 0000-0003-3516-2942

An employee of the Warsaw University of Technology since 1965, a scholarship holder of the Alexander v. Humboldt Foundation in the 1970s, internships and work in German universities and companies in the 1980s. In 1978 he organizes the first scientific conference on industrial robotics in Poland, in 1985 WNT publishes the first Polish monograph on industrial handling machines written under his supervision, in the past decade the REA publishing house has published the first Polish mechatronics textbooks written under his supervision: „Mechatronics” (2002), "Fundamentals of Mechatronics" (2006) and two-volume "Mechatronic Devices and Systems" (2009). A specialist in the field of drive and control of machines and industrial robots. Director of the Institute of Automatic Control and Robotics at the Mechatronics Faculty of the Warsaw University of Technology in 1994-2012; Member of the Scientific Council of the Industrial Institute of Automation and Measurements (PIAP) in the years 20032017; Vice-Chairman of the Technical-Education-Committee at the Polish-German AHK in Warsaw in the years 2010-2018. The founder of the scientific and technical consulting company marlndustry 4.0 in the area of mechatronization, automation, robotization, computerization and internetization of industrial production - Industry 4.0, from 2016 